\title{
Gas, Oil, and Water Production in the Wind River Basin, Wyoming
}

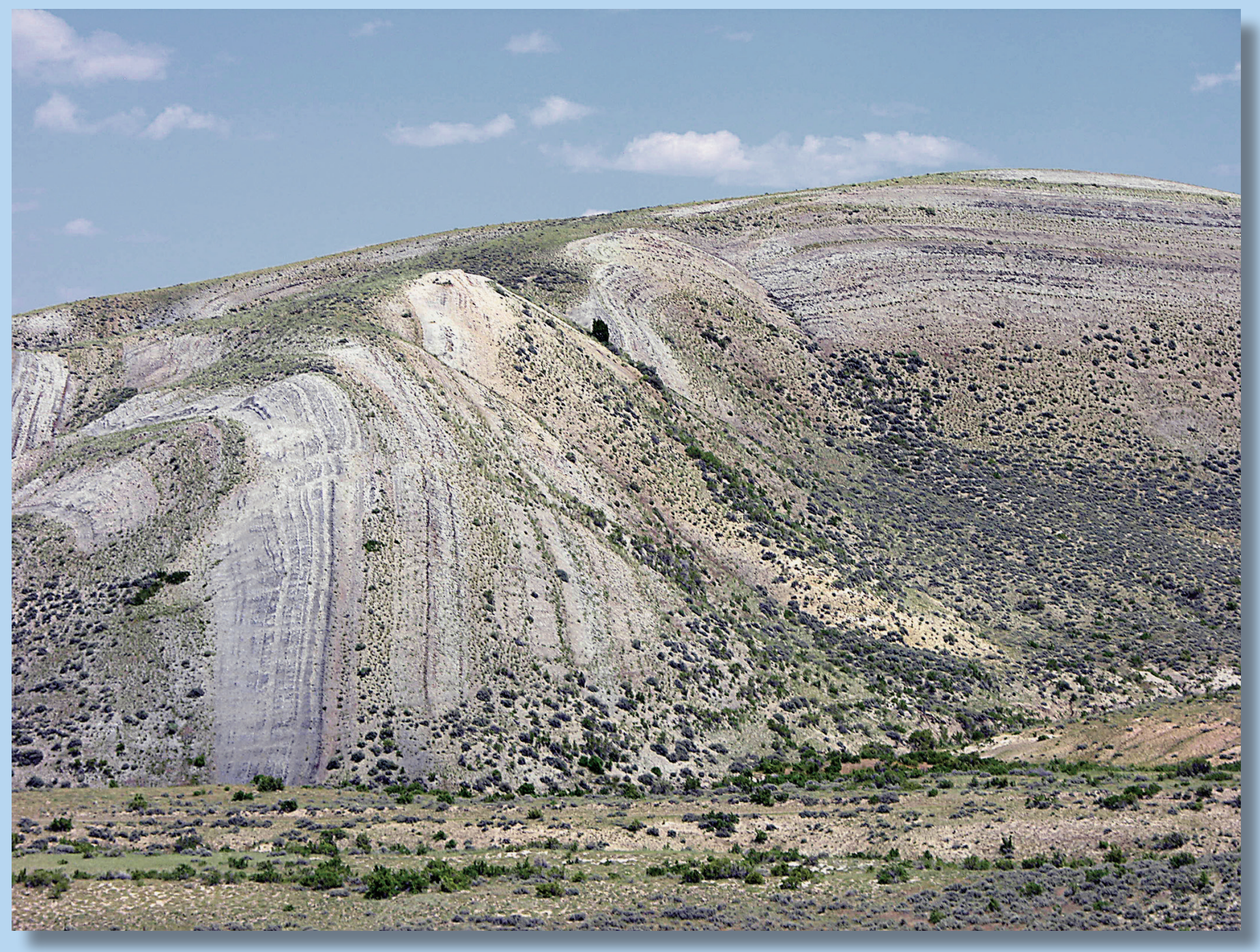

Scientific Investigations Report 2008-5225 


\section{Cover photo}

Outcrop of Mowry Shale at Conant Creek anticline, southern Wind River Basin, Wyoming. Photograph by C.J. Schenk 


\section{Gas, Oil, and Water Production in the Wind River Basin, Wyoming}

By Philip H. Nelson, Patrick K. Trainor, and Thomas M. Finn

Scientific Investigations Report 2008-5225 


\title{
U.S. Department of the Interior \\ KEN SALAZAR, Secretary
}

\author{
U.S. Geological Survey \\ Suzette M. Kimball, Acting Director
}

U.S. Geological Survey, Reston, Virginia: 2009

For product and ordering information:

World Wide Web: http://www.usgs.gov/pubprod

Telephone: 1-888-ASK-USGS

For more information on the USGS - the Federal source for science about the Earth, its natural and living resources, natural hazards, and the environment:

World Wide Web: http://www.usgs.gov

Telephone: 1-888-ASK-USGS

Any use of trade, product, or firm names is for descriptive purposes only and does not imply endorsement by the U.S. Government.

Although this report is in the public domain, permission must be secured from the individual copyright owners to reproduce any copyrighted materials contained within this report.

Suggested citation:

Nelson, P.H., Trainor, P.K., and Finn, T.M., 2009, Gas, oil, and water production in the Wind River Basin, Wyoming: U.S.

Geological Survey Scientific Investigations Report 2008-5225, 24 p. 


\section{Contents}

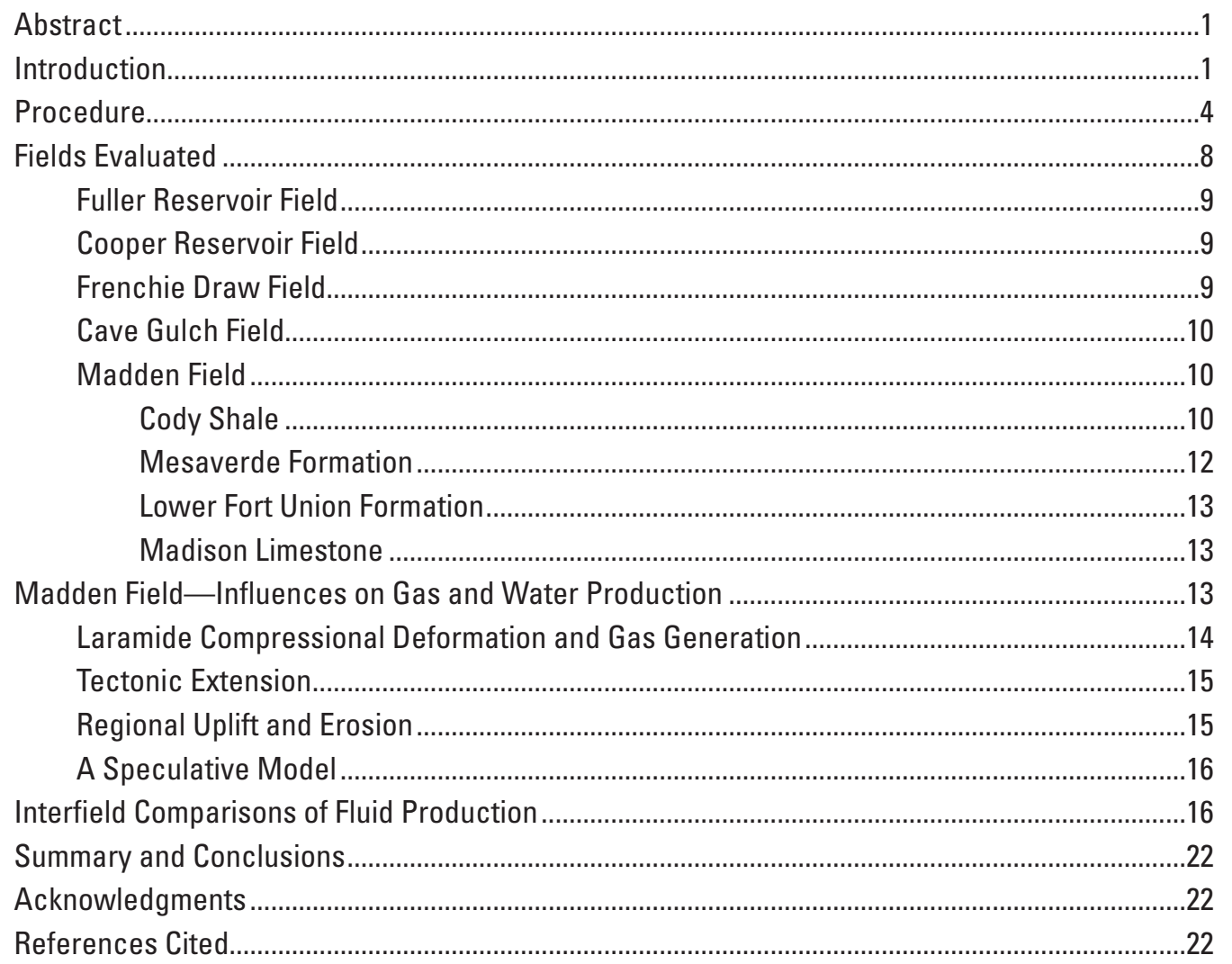




\section{Plates}

1-5. Gas, Oil, and Water Production From:

1. Fuller Reservoir Field

2. Cooper Reservoir Field

3. Frenchie Draw Field

4. Cave Gulch Field

5. Three Formations in Madden Field

6. Water Versus Gas Production and Oil Versus Gas Production for Three Formations in Madden Field

7. Gas, Oil, and Water Production From Madison Limestone, Madden Field

8. Burial History, Thermal Maturity, Gas Generation, and Tectonic Regimes in Madden Field

\section{Figures}

1. Map showing the areas of fields evaluated in the Wind River Basin, Wyoming ...............2

2. Stratigraphic chart of the Wind River Basin, Wyoming …….............................................

3. Example of fluid production versus time and corresponding log-log production diagrams for the Federal 13-18 well in Fuller Reservoir field, Wind River Basin, Wyoming

4. Example of fluid production versus time and "vector" diagrams of changes in production with time, Cooper Reservoir Unit 11 well, Wind River Basin, Wyoming.

5. Water versus gas production rates plotted on a log-log diagram ....................................

6. Oil versus gas production rates plotted on a log-log diagram ........................................8

7. Cross section showing conceptual distribution of gas along a south-north section in the Wind River Basin

8. Diagram showing pressure from drillstem tests as a function of depth in the Madden field.

9. Conceptual diagram of gas and water flow into a well producing from two siltstones in the Madden field.

10. Diagram showing water versus gas production rates in five fields, Wind River Basin

11. Diagram showing oil and gas production in eight fields, Wind River Basin....................19

12. Vector diagrams of six tight gas accumulations, Wind River Basin ................................20

13. Normalized vector diagrams for six tight gas accumulations, Wind River Basin ..........21 


$\begin{array}{ll}\begin{array}{l}\text { Abbreviations Used in This Report } \\ { }^{\circ} \mathrm{F}\end{array} & \text { degree Fahrenheit } \\ { }^{\circ} \mathrm{F} / 100 \mathrm{ft} & \text { degree Fahrenheit per } 100 \text { feet } \\ \mathrm{bbl} / \mathrm{day} & \text { barrels per day } \\ \mathrm{bbl} / \mathrm{mmscf} & \text { barrels per million standard cubic feet } \\ \mathrm{ft} & \text { foot, feet } \\ \mathrm{m} & \text { meter, meters } \\ \mathrm{Ma} & \text { mega-annum (date) } \\ \mathrm{m} . \mathrm{y} . & \text { million years (interval) } \\ \mathrm{m} / \mathrm{m} . \mathrm{y} . & \text { meters per million years } \\ \mathrm{mscf} / \mathrm{day} & \text { thousand standard cubic feet per day } \\ \mathrm{mD} & \text { millidarcy } \\ \mathrm{psi} & \text { pounds per square inch } \\ \mathrm{psi} / \mathrm{ft} & \text { pounds per square inch per foot } \\ \mathrm{R} & \text { vitrinite reflectance } \\ \mathrm{scf} & \text { standard cubic feet } \\ \mathrm{scf} / \mathrm{bbl} & \text { standard cubic feet per barrel } \\ & \end{array}$

\section{Conversion Factor}

SI to Inch/Pound

\begin{tabular}{lcl}
\hline Multiply & By & To obtain \\
\hline meter $(\mathrm{m})$ & 3.281 & foot $(\mathrm{ft})$ \\
\hline
\end{tabular}


Left blank intentionally 


\title{
Gas, Oil, and Water Production in the Wind River Basin, Wyoming
}

\author{
By Philip H. Nelson, Patrick K. Trainor, and Thomas M. Finn
}

\section{Abstract}

Gas, oil, and water production data were collected from the Fuller Reservoir, Cooper Reservoir, Frenchie Draw, Cave Gulch, and Madden fields in the Wind River Basin, Wyoming. These fields produce from the Mississippian Madison Limestone, the Upper Cretaceous Cody Shale and Mesaverde Formation, and the Paleocene lower unnamed member and Shotgun Member of the Fort Union Formation. Daily rates representative of early production from individual wells were derived from diagrams of gas, oil, and water production. For each producing interval, summary diagrams of oil versus gas and water versus gas production show fluid production rates, the change in rates during 5 years, the water-gas and oil-gas ratios, and the fluid type. These diagrams permit well-to-well and field-to-field comparisons. Fields producing dry gas are distinguished from those producing wet gas or oil. Fields producing water at low rates (water dissolved in gas in the reservoir) can be distinguished from fields producing water at moderate or high rates, and the water-gas ratios are quantified. Within the six fields having low permeability (tight gas) accumulations, few of the intervals studied produced water at rates low enough to be attributed solely to water dissolved in gas in the reservoir.

Diagrams of water and gas production from tight gas accumulations in three formations in the Madden field show that (1) water production either increased or decreased with time in all three formations, (2) increases and decreases in water production were greater in the Cody Shale than in either the Mesaverde Formation or the lower unnamed member of the Fort Union Formation, (3) the gas production rate declined more slowly in the lower part of the Fort Union Formation than in the Cody Shale or the Mesaverde Formation, (4) changes in gas and water production were not related to their initial production rates, and (5) there appears to be no relation between well location and the magnitudes or trends of gas and water production.

To explain the apparent independence of gas and water production in the Cody Shale and Mesaverde Formation, a two-step scenario is proposed: gas was generated and emplaced under the compressive stress regime resulting from Laramide tectonism; then, fractures formed during a subsequent period of stress relaxation and extension. Gas is produced from the pore and fracture system near the wellbore, whereas water is produced from a larger scale system of extension fractures. The distribution of gas and water in the lower Fort Union resulted from a similar scenario, but continued generation of gas during post-Laramide extension may have allowed its more widespread distribution.

\section{Introduction}

This study examined production of gas, oil, and water from low-permeability (tight gas) accumulations, in order to compare the production characteristics of such accumulations within a basin - in this case, selected fields in the Wind River Basin of Wyoming (fig. 1) - and, eventually, among basins. A few gas and oil reservoirs of moderate or even high permeability were included to serve as reference cases. In all examples, we looked for (1) wells with early production so that we could sample the fluid production when the reservoir was first tapped and avoid well interference effects, (2) continuity of production so that production trends with time could be sampled, (3) indications that records are valid, and (4) documentation of depths of producing intervals and stimulation methods.

Productive strata examined in the five fields included in our study_Fuller Reservoir, Cooper Reservoir, Frenchie Draw, Cave Gulch, and Madden-are Mississippian, Late Cretaceous, and Paleocene in age (fig. 2); data are presented in plates 1-7. The youngest reservoirs studied are in the Shotgun Member of the Fort Union Formation in Fuller Reservoir field (pl. 1), which is considered to be a conventional, predominantly oil, reservoir within the Waltman Shale Total Petroleum System (Roberts, Roberts, and others, 2007). Its hydrocarbons are derived from the underlying Waltman Shale Member of the Fort Union Formation (fig. 2). Gas accumulations in the other four fields are considered as continuous accumulations within the Cretaceous-Lower Tertiary Composite Total Petroleum System (Johnson and others, 2007): the lower unnamed member of the Fort Union Formation (hereafter referred to as lower Fort Union Formation) in Cooper Reservoir (pl. 2); the lower Fort Union Formation in Frenchie Draw (pl. 3); the Lance Formation in Cave Gulch field (pl. 4); and the lower Fort Union Formation, the Mesaverde Formation, and the Cody 


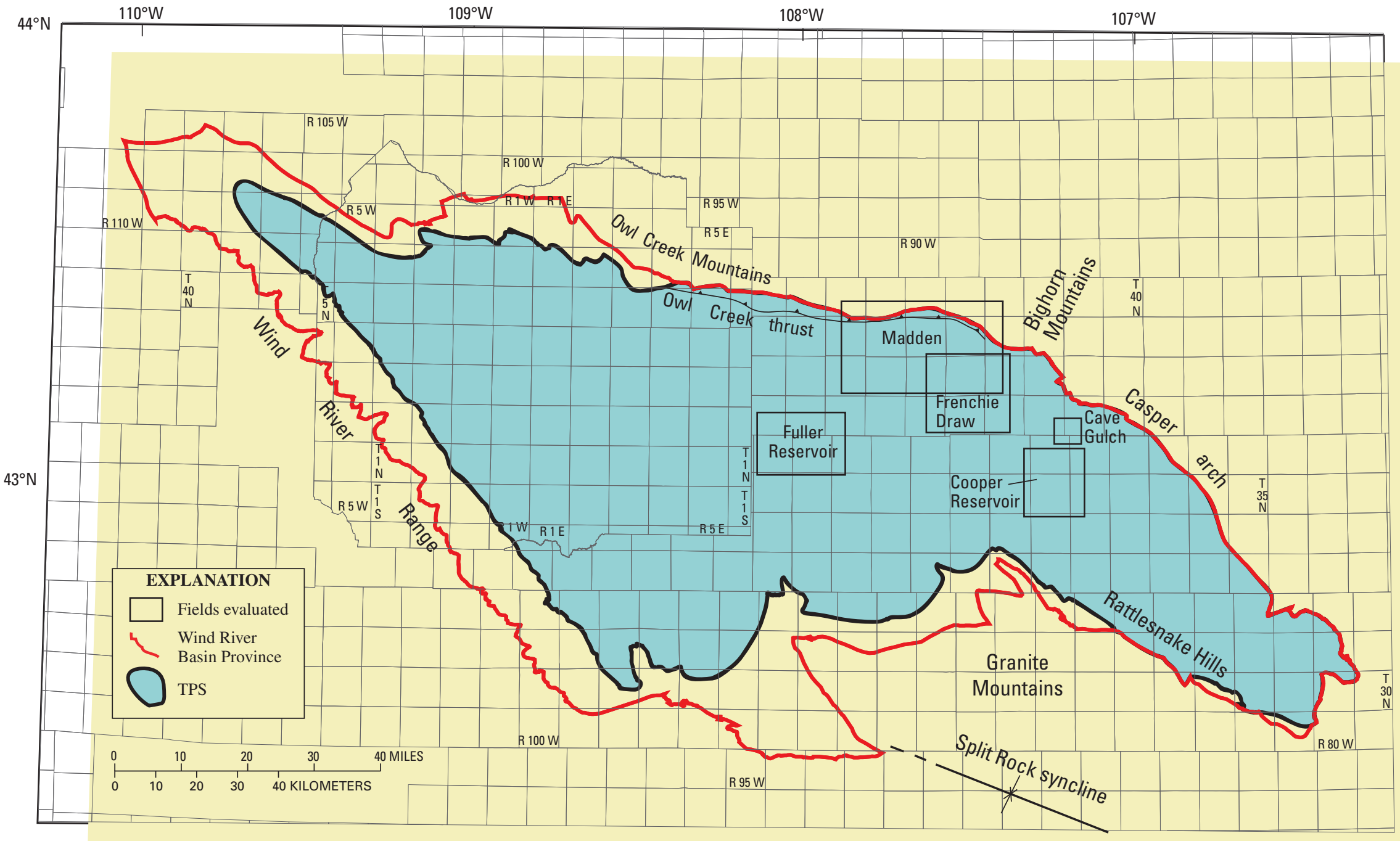

Figure 1. Wind River Basin, Wyoming, showing areas of fields evaluated. Modified from Johnson and others (2007). TPS, Cretaceous-Lower Tertiary Composite Total Petroleum System. 


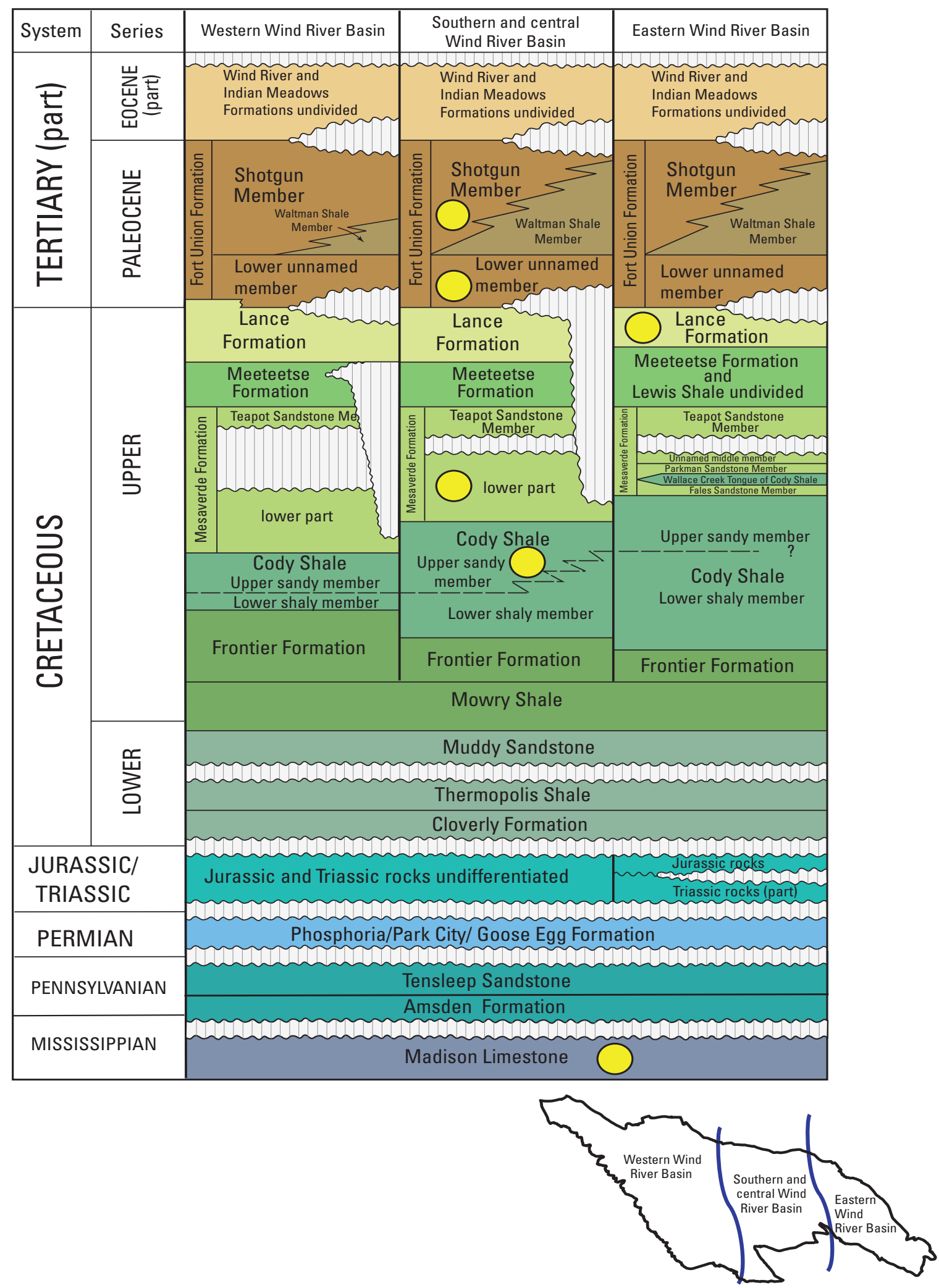

Figure 2. Stratigraphic chart of the Wind River Basin, Wyoming. Yellow dots indicate formations for which fluid production is documented in this report. Modified from Johnson and others (2007) and Kirschbaum and others (2007). 
Shale in the Madden field (pls. 5, 6). In addition to data from these fields, production data from the Mississippian Madison Limestone in the Madden field, which produces gas at high rates and is considered to be a conventional accumulation, are also included (pl. 7). Gas from the Madison is believed to be derived from younger rocks in the Cretaceous-Lower Tertiary Total Petroleum System (Johnson and others, 2007)). Other gas fields in the Wind River Basin (Pavillion, Muddy Ridge, and Waltman) had inadequate water production records and were not studied.

Further perspective on the Cretaceous and Tertiary stratigraphy of the Wind River Basin is provided in the form of descriptions, measured sections, and cross sections by Finn (2007), Johnson (2007), and Johnson and others (2007).

The results of decline curve analysis, commonly used by reservoir engineers to quantify the productive capacity of wells, may be difficult to apply in the context of our study because of high variability among gas accumulations, and those results do not provide a uniform yardstick for interreservoir comparison. Furthermore, owing to changes in production practices, erratic records, low-quality data, and changes in the producing interval (recompletions) during the lifetime of a well, cumulative production figures were not used in this study. We consider water production to be an important characteristic of tight gas systems, so we address its behavior along with that of gas and oil. For these reasons, we devised a simple system of portraying gas, oil, and water production that can be used for any gas or oil reservoir as long as production records are of sufficient reliability, continuity, and length.

Ultimately, variations in gas, water, and oil production should be viewed as a tool that leads to better understanding of the circumstances of hydrocarbon emplacement in varied geologic settings, particularly for tight gas reservoirs, which at this time are not well understood. This report concludes with an attempt to link the disparate water production records from various reservoirs in the Madden field to the timing of gas generation and tectonic development in the northern part of the Wind River Basin.

\section{Procedure}

Monthly production data were taken from the IHS Energy Group production data base (IHS Energy Group, 2007) and were checked against data available on the Wyoming Oil and Gas Conservation Commission web site (Wyoming Oil and Gas Conservation Commission, 2007). Daily production rates were computed by dividing monthly volumes by the number of days of production in a month. Measurements of (1) gas rate, in thousands of cubic feet per day (mcf/day); (2) water rate, in barrels per day (bbl/day); (3) oil rate, in barrels per day (bbl/day); (4) water-gas ratio, in barrels of water per million standard cubic feet of gas (bbl/mmscf); and (5) gas-oil ratio, in standard cubic feet of gas per barrel of oil (scf/bbl), are all plotted on a logarithmic scale as a function of time (fig. 3A). To determine a representative flow rate of gas, oil, or water from a well, we selected a time interval early in the history of a given production record for which fluid production was judged to be representative of flow (fig. $3 A$ ). This time interval, referred to as "initial" time in this report, was generally selected to be about 2 years after commencement of production; such delay served to eliminate early transients and early changes in equipment, and it reduced the likelihood that fracturing fluids were included in the water tally.

The method of determining daily rates of gas, oil, and water production during a 3-month interval is illustrated by the example in figure $3 A$. The resulting rates were then posted on summary diagrams with bilogarithmic ("log-log") scales (figs. $3 B$ and $3 C$ ), which accommodate wide ranges of production rates. With the use of bilogarithmic axes, constant ratios of production rates lie on 45-degree lines; the ratio increases upward and to the left. Zero values of water or oil, which cannot be accommodated on a logarithmic scale, are plotted below the dashed lines near the bottom of the diagram.

To show the change in gas and water production in each well, a second 3-month average was computed 5 years after the initial average (fig. 4A). These "5-year" gas and water production figures are plotted on the log-log production diagram (solid triangle in fig. 4B). Each 5-year value is linked to its initial value (solid square in fig. $4 B$ ) by a dashed line, producing a vector that shows the amount and direction of change in water and gas production with time. A vector of a given length and angle represents the same fractional change in daily gas and water production regardless of where it is positioned on the diagram. In the example shown in figure 4, both gas and water production decreased with time, and the water-gas ratio decreased slightly with time.

To clarify the relative changes in water and gas production among wells, a log-log diagram of the change in water and gas production places all early-time production at a common origin (solid square at 1,1 in fig. $4 C$ ); changes in production during a 5-year span can then be compared among wells. The length and orientation of each vector is the same in figures $4 B$ and $4 C$, but the origin, which is its value at initial time, has been translated to the center position $(1,1)$ of the diagram in figure $4 C$. In this example, the data were complete at the 5 -year interval, but in a few cases where data were missing, values from an earlier time ( 3 or 4 years after the initial time) were extrapolated to 5 years.

If one examines the amount of produced water, the question arises as to how much water could be dissolved in the gas in the reservoir and then released at the surface. The amount of water dissolved in gas in reservoirs increases with increasing temperature and decreases with increasing pressure (McCain, 1990, p. 461). Likewise, the amount of water remaining in gas delivered to the pipeline depends upon pipeline pressure and temperature. The amount released at the surface is the difference between these two quantities, and it can be represented on a water-gas production diagram (fig. 5). The heavy blue diagonal lines represent the amount of water released at the surface by reservoirs at three depths $-8,000,12,000$, 

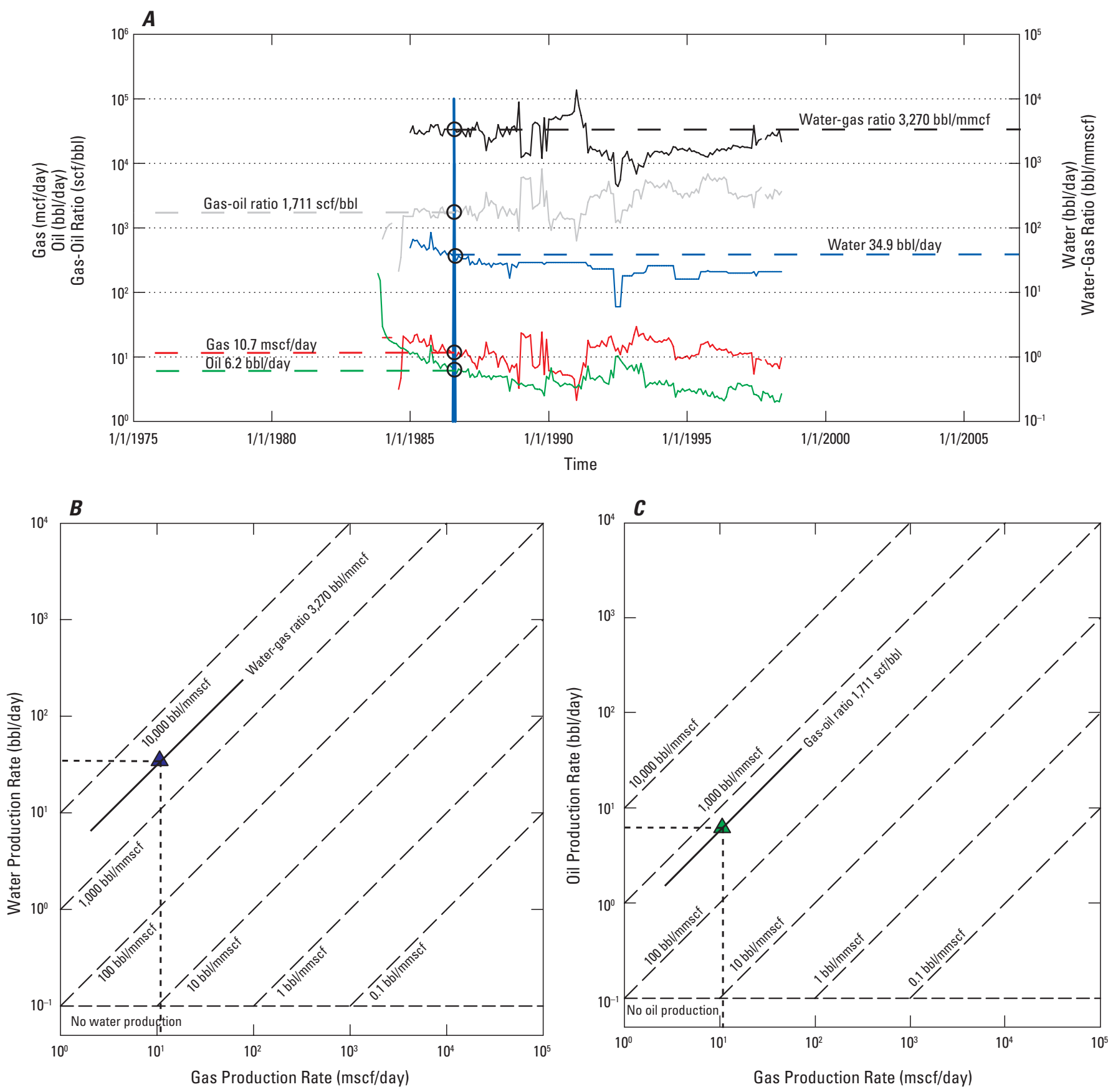

Figure 3. Example of fluid production versus time and corresponding log-log production diagrams, for the Federal 13-18 well in Fuller Reservoir field, Wind River Basin, Wyoming. A, Production of gas, oil, and water, and gas-oil ratio and water-gas ratio, all versus time. Vertical blue line indicates "initial" time, which is generally about two years after onset of production. Posted values are averages for months of July, August, and September, 1986. Open circles, values of production rates and ratios. $B$, Water versus gas production; scales are logarithmic. Horizontal dashed line, water production rate; vertical dashed line, gas production rate (values from part A); blue triangle, water-gas ratio, which falls on a 45-degree line. C, Oil versus gas production; scales are logarithmic. Horizontal dashed line, oil production rate; vertical dashed line, gas production rate (values from part A); green triangle, gas-oil (or oil-gas) ratio, which falls on a 45 -degree line. A gas-oil ratio of 1,711 scf/bbl is equivalent to an oil-gas ratio of $584 \mathrm{bbl} / \mathrm{mmscf}$. bbl/day, barrels per day; bbl/mmscf, barrels per million standard cubic feet; $\mathrm{mscf} / \mathrm{day}$, thousand standard cubic feet per day; scf/bbl, standard cubic feet per barrel. 

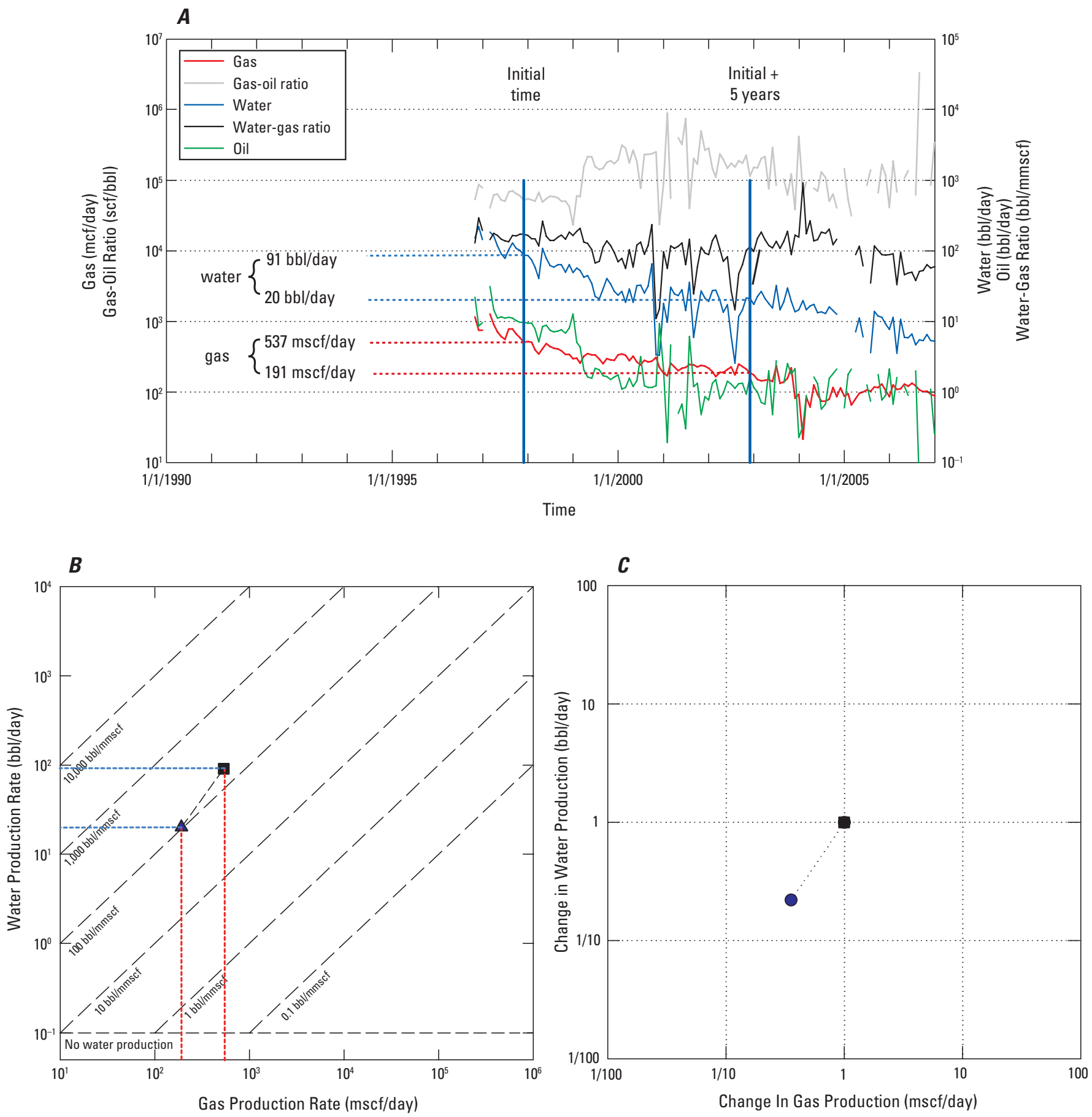

Figure 4. Example of fluid production versus time and "vector" diagrams of changes in production with time, Cooper Reservoir Unit 11 well, Wind River Basin, Wyoming. A, Production of gas, water, and oil, and variation in gas-oil ratio and in water-gas ratio versus time. Open circles, values of production rates and ratios. $B$, Vector diagram showing water versus gas production; scales are logarithmic. Square, gas and water production at initial time; triangle, gas and water production at 5-year time, thus marking the head and tail of a vector. $C$, Normalized vector diagram showing change in water production versus change in gas production; scales are logarithmic axes. Square, initial-time value, placed at center of diagram so all vectors for a field share a common origin; circle, initial +5 year values. bbl/day, barrels per day; bbl/mmscf, barrels per million standard cubic feet; mscf/day, thousand standard cubic feet per day; scf/bbl, standard cubic feet per barrel. 


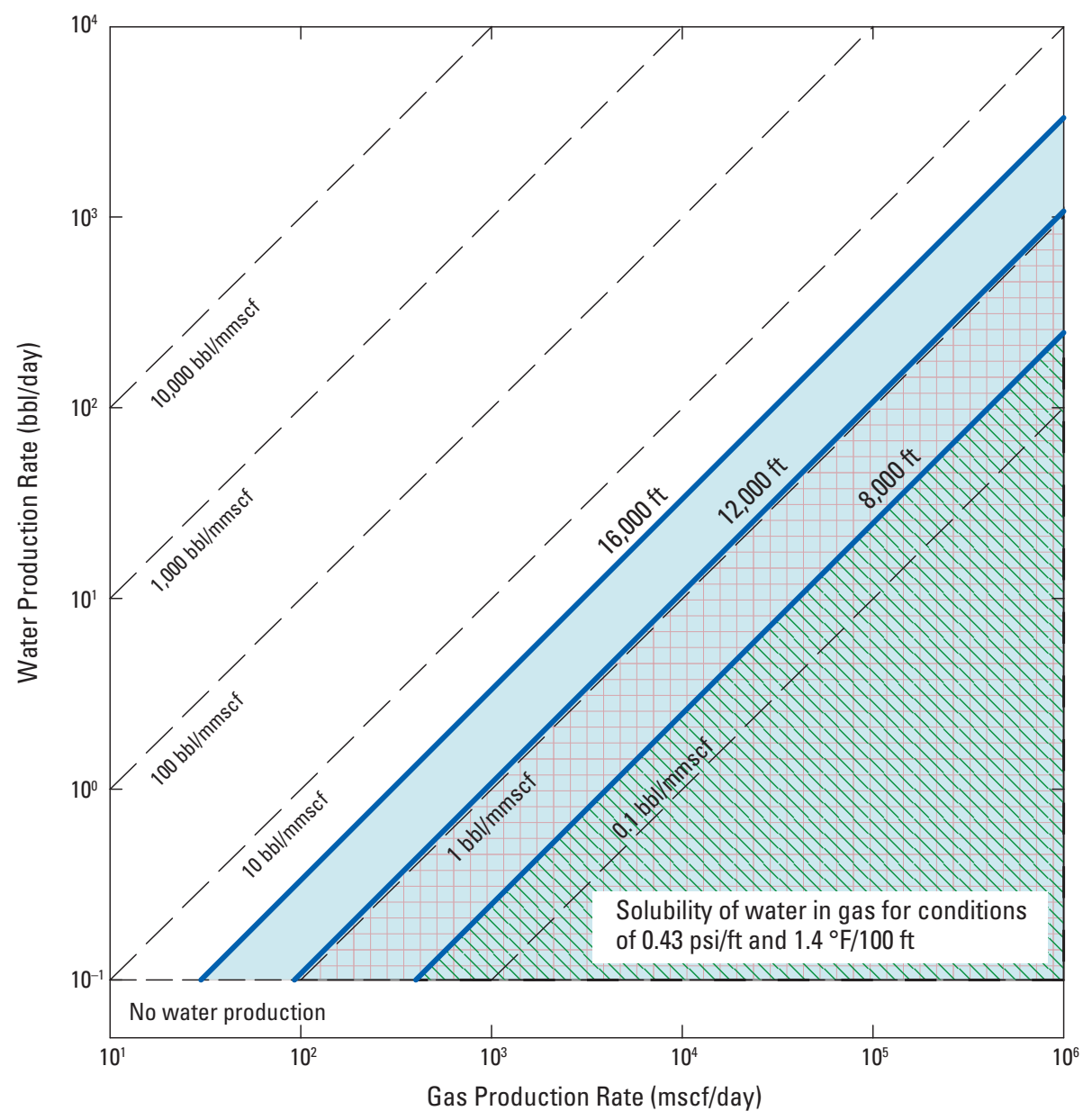

Figure 5. Water versus gas production rates plotted on a log-log diagram. Three diagonal blue lines give the upper bound of water-gas ratio for liquid water released at a surface separator, based on McCain (1990). For example, a gas reservoir at $12,000 \mathrm{ft}$ depth can hold as much as 1 barrel of dissolved, low-salinity water for every 1 million standard cubic feet of gas (bbl/mmscf), and a gas reservoir at 16,000 $\mathrm{ft}$ depth can hold as much as $3 \mathrm{bbl} / \mathrm{mmscf}$. ${ }^{\circ} / 100 \mathrm{ft}$, degrees Fahrenheit per 100 feet; bbl/day, barrels per day; mscf/day, thousand standard cubic feet per day; psi/ft, pounds per square inch per foot.

and 16,000 feet (ft). A pressure gradient of 0.433 pounds per square inch per foot $(\mathrm{psi} / \mathrm{ft})$ and a temperature gradient of $1.4^{\circ}$ Fahrenheit per 100 feet $\left({ }^{\circ} \mathrm{F} / 100 \mathrm{ft}\right)$ were assumed in each case. Surface conditions at the separator were assumed to be $80^{\circ} \mathrm{F}$ and 1,000 psi. Roughly 3 barrels of water can be dissolved in 1 million standard cubic feet (mmscf) of gas at a depth of $16,000 \mathrm{ft}$, but only 0.2 barrels of water can be dissolved in gas at pressure and temperature conditions corresponding to a reservoir at a depth of 8,000 ft (fig. 5). For the gas accumulations examined in this study, the amounts of water that can be dissolved in gas in the reservoir and released as water at the surface are generally less than the amounts of water actually produced.

Because oil and gas types are defined as a function of gas-to-oil ratios (McCain, 1990), the fluid types can be displayed on the log-log oil production versus gas production diagrams (fig. 6). Black and volatile oil types have gas-oil ratios of less than 3,300 standard cubic feet per barrel (scf/bbl) of oil, and they occupy the upper left corner of an oilgas production diagram (fig. 6). In a retrograde gas reservoir, liquid condenses in the reservoir as reservoir pressure declines. Gas-oil ratios in retrograde gas reservoirs typically range from 3,300 to $5,000 \mathrm{scf} / \mathrm{bbl}$, but they can have values as high as $150,000 \mathrm{scf} / \mathrm{bbl}$; these reservoirs occupy a central diagonal band on an oil-gas diagram (fig. 6). Wet gases, also called condensate gases, have gas-oil ratios in excess of $50,000 \mathrm{scf} / \mathrm{bbl}$ ( $<20 \mathrm{bbl}$ of condensate/mmcf of gas), and they occupy the lower right corner of the diagram (fig. 6). Dry gas produces no oil, and corresponding points are plotted at the bottom of the diagram.

Fluids from many of the wells examined in this study were produced from several perforated zones; consequently, 


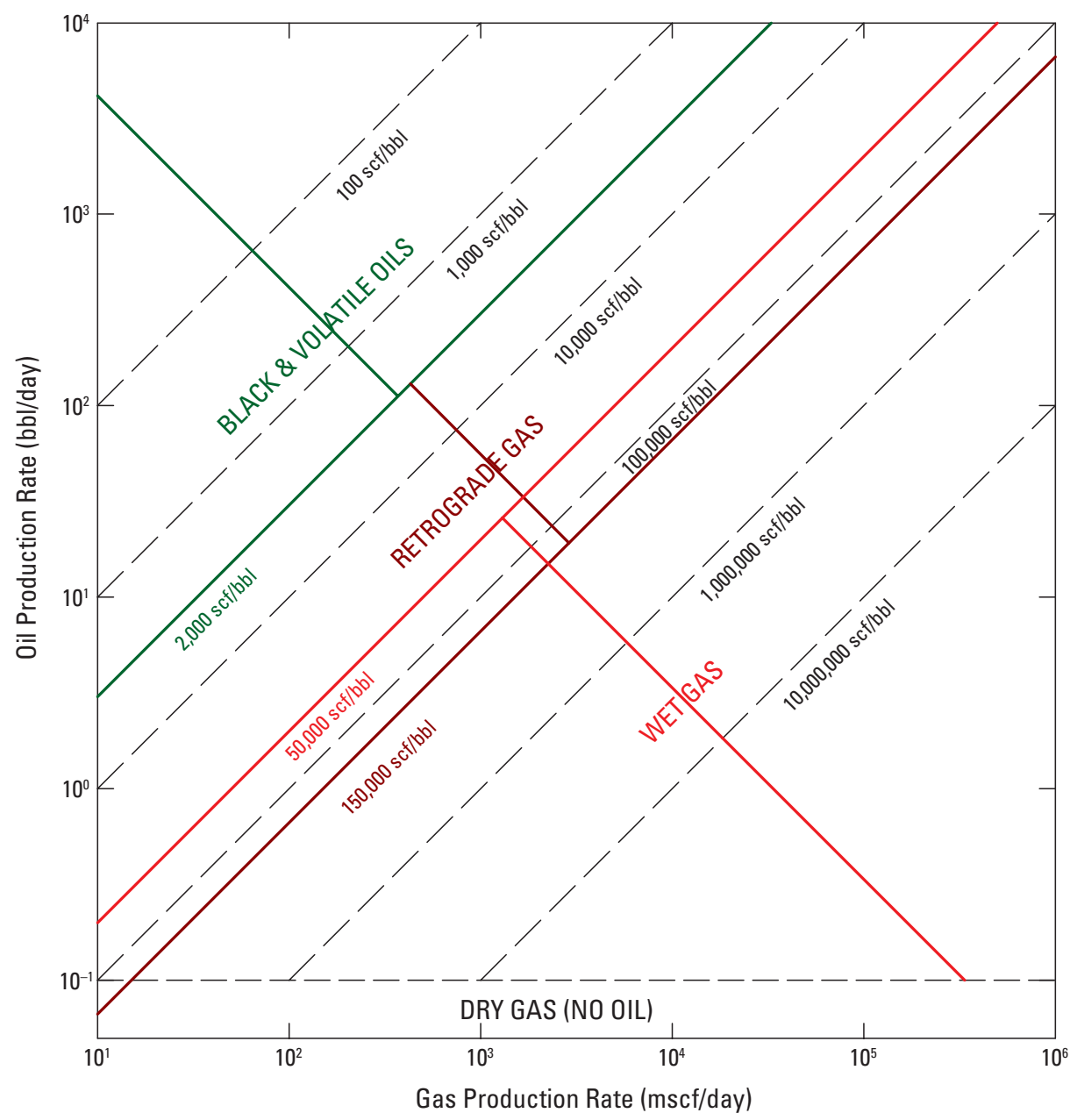

Figure 6. Oil versus gas production rates plotted on a log-log diagram. Fields indicate three reservoir fluid types, based on McCain (1990). Diagonal lines up to the right, bounds for each fluid type; diagonal lines down to the right, range of each fluid type. $\mathrm{bbl} / \mathrm{day}$, barrels per day; mscf/day, thousand standard cubic feet per day; scf/bbl, standard cubic feet per barrel.

the fluid volumes recorded at the surface represent the combined inflow from several intervals. Even so, the resulting fluid production can be regarded as representative of a formation in a particular field, possibly even more representative of a formation than production from a single interval.

\section{Fields Evaluated}

The following discussions of fluid production are related to the data displayed in plates $1-7$, which are arranged by area and geologic formation. A few general points are summarized here to avoid repetition.

- Perforated intervals and duration of production, displayed on the diagrams of daily production versus time in plates $1-7$, were taken from IHS well data (IHS Energy Group, 2007) and were also spot checked against data available on the Wyoming Oil and Gas Conservation Commission web site (Wyoming Oil and Gas Conservation Commission, 2007).

- Most perforated intervals were stimulated before production commenced. On the diagrams of daily production versus time, an " $F$ " denotes hydraulic fracturing, and an "A" denotes acidization.

- Water rates were generally more erratic ("noisier") than gas production rates. Water production records are considered less reliable than gas or oil production records, because there is less incentive to report water production carefully. For this reason, inconsistencies in reporting procedures may contribute to the erratic 
nature of reported water-production rates. As a consequence, the water-gas ratio tends to mimic the water production.

- Gas, oil, and water production rates, water-gas ratio, and gas-oil ratio are all displayed on logarithmic scales on the diagrams of production versus time. Although six-decade scales are used, scales differ from area to area to accommodate different production rates and ratios.

- Production was erratic between 1985 and 1990 when wells were produced for fewer than 30 days per month in response to market conditions.

\section{Fuller Reservoir Field}

In the Fuller Reservoir field (fig. 1-1 of pl. 1), oil and gas are produced from the Shotgun Member of the Paleocene Fort Union Formation at fairly low rates from depths of 3,000 ft. Specht (1989) described the trap types as "multiple local stratigraphic traps on large structural nose, possible local structural closure." Reservoir porosity ranges from 18 to 30 percent and permeability ranges from 0.1 to 50 millidarcies (mD) (Specht, 1989), so this reservoir is not in the lowporosity, low-permeability category. The production mechanism was initially solution-gas drive, according to Specht (1989). Cumulative production through 2005 from 33 wells was 2.3 million barrels of oil and 4.4 billion cubic feet of gas (Roberts, Finn, and others, 2007). This field also produces from the lower Fort Union Formation, but those records were inadequate for our purpose.

This shallow, densely drilled field covering several square miles is represented here by 18 wells (fig. 1-1 of pl. 1); production diagrams are shown for 7 of the 18 wells (pl. 1). As shown on the water-gas and oil-gas diagrams (figs. 1-2 and $1-3)$, gas production from 18 wells at initial times ranged from 5 to $84 \mathrm{mcf} /$ day, water production ranged from 10 to $142 \mathrm{bbl} / \mathrm{day}$, and oil production ranged from 6 to $30 \mathrm{bbl} /$ day. All wells were stimulated prior to production either by hydraulic fracturing or by acidization or both.

Nine of the 18 wells had adequate records after 7 years of production; thus, we were able to extract initial-to-5-year production vectors for those 9 wells (figs. 1-4, 1-5 of pl. 1). Water production was either flat or increased with time, while gas production generally decreased with time. Gas production did increase in 2 of the 9 wells; this apparent increase could represent either an artifact of record-keeping or a change in production practice.

In summary, in the Fuller Reservoir field, gas and oil production was low, gas decline rates were low, oil production tended to track gas production, water production was high, and the water-gas ratio was extremely high.

\section{Cooper Reservoir Field}

Gas production from sandstones in the lower Fort Union Formation commenced in the early 1960s (Boyd, 1969), at which time three sandstones at depths from 3,300 to $3,700 \mathrm{ft}$ were completed and produced. Production then ceased for some time but recommenced in the 1990s when multistage hydraulic fracturing methods were applied to both the lower Fort Union Formation and the Lance Formation (Dempsey and others, 2001). According to Dempsey and others (2001), the sandstone reservoirs originated as braided and meandering stream deposits, isolated by shales, and gas-bearing and waterbearing units were in close proximity. Porosity ranges from 12 to 20 percent and permeability ranges from 0.01 to $1.0 \mathrm{mD}$.

Seven wells in Cooper Reservoir field were selected to give continuous production records and good spatial coverage (fig. 2-1 of pl. 2). The initial daily gas rates in the seven wells ranged from a minimum of 205 to a maximum of $2,040 \mathrm{mcf} /$ day. Initial water production ranged from 5 to $130 \mathrm{bbl} /$ day (fig. 2-2), and initial oil production ranged from 1.6 to $15 \mathrm{bbl} /$ day (fig. 2-3). Although records show that oil production was erratic, oil production does track gas production in wells $7,8,11$, and 14 , as shown by the roughly constant gas-oil ratio (light gray trace) on the production-versus-time diagrams (pl. 2). The increase of oil with time in well 12 is unexplained.

Water-gas ratios plotted in figure $2-2$ of plate 2 range from around 10 to more than $100 \mathrm{bbl} / \mathrm{mmcf}$ of gas, or about 100 times as much water as could be dissolved in gas at reservoir conditions; thus, free water was being produced. The water-gas ratio either remained constant or increased with time (see daily production diagrams of pl. 2 and fig. 2-5). Gas-oil ratios for wells 6 and 24 were not plotted in figure $2-3$ because oil production was erratic. Gas-oil ratios for the remaining five wells fall within the wet gas domain on the oilgas diagram (fig. 2-3).

\section{Frenchie Draw Field}

Normark (1978) described Frenchie Draw field as "a combination structural-stratigraphic trap that produces gas and condensate from a number of discontinuous sandstones in the lower Fort Union Formation. ... Reservoirs appear to be composed of sandstone lenses a few hundred acres in areal extent and of widely varying quality." The field is located on a north-plunging structural nose about 6 miles south of the Madden anticline (fig. 3-1 of pl. 3). Porosity ranges from 6 to 12 percent and permeability ranges from 0.1 to $0.2 \mathrm{mD}$ (Mueller, 1989). Normark (1978) reported that initial pressures throughout a wide depth range fit a pressure gradient of $0.44 \mathrm{psi} / \mathrm{ft}$ and that bottom-hole temperatures range from $195^{\circ}$ to $215^{\circ} \mathrm{F}$. On the basis of temperatures measured with drillstem tests, temperature gradients range from $1.6^{\circ}$ to $2.0^{\circ} \mathrm{F}$ per $100 \mathrm{ft}$ in Frenchie Draw field (Nelson and Kibler, 2007). 
The seven wells with production records (pl. 3) include the discovery well, Frenchie Draw Unit 1, completed in 1961. Gas production from this well declined for the first 8 years, then held steady for the next 22 years. Other wells seem to show a similar pattern of decline followed by years of steady gas, oil, and water production (pl. 3). Initial rates of water production were high, corresponding with water-gas ratios ranging from 40 to $630 \mathrm{bbl} / \mathrm{mmcf}$, and those rates increased further after the initial time (production diagrams of pl. 3 and figs. 3-4 and 3-5 of pl. 3). High rates of water production are sustainable economically because surface disposal of water is permitted for this field. Oil-to-gas ratios are somewhat higher than the upper limit for a wet gas (fig. 3-3 of pl. 3), and the ratio could be categorized as representing a retrograde gas (fig. 6).

\section{Cave Gulch Field}

Cave Gulch field (pl. 4) has some characteristics of a conventional gas reservoir (Montgomery and others, 2001). In the Lance Formation, porosity ranges from 9 to 19 percent and permeability ranges from 0.1 to $50 \mathrm{mD}$. Water lies below gas (T. Enterline, Bill Barrett Corp., oral commun., 2008). Pressures are normal, and pressure-depth ratios are about 0.41 to $0.43 \mathrm{psi} / \mathrm{ft}$. On the other hand, Cave Gulch field also has some characteristics of a tight gas system (Montgomery and others, 2001). Lance sandstones are very fine to fine grained. The productive interval in strata from the upper Meeteetse Formation to the lower part of the Fort Union Formation extends for nearly 5,000 vertical feet. Wells are hydraulically fractured prior to production. A large portion of the formation is low permeability of less than $0.1 \mathrm{mD}$ (T. Enterline, Bill Barrett Corp., oral commun., 2008). Above the basal sandstone, which is $214 \mathrm{ft}$ thick, are individual fluvial channel sandstones ranging in thickness from 3 to $40 \mathrm{ft}$, and stacked channel sandstone units are as thick as $130 \mathrm{ft}$ (Johnson, 2007). The position of a well is a critical factor in its productivity, as the field is located in a faulted anticlinal structure beneath the Casper Arch thrust. Fracturing is believed to play a key role in well productivity in Cave Gulch field.

Nine of 10 wells shown on plate 4 lie on a northwestsoutheast line 1.6 miles in length (fig. 4-1 of pl. 4) (the tenth well lies about 1 mile west of the Cave Gulch Unit boundary). Two years after commencement of production, gas production ranged from 160 to $7,000 \mathrm{mcf} /$ day and water production ranged from 2 to $53 \mathrm{bbl} /$ day for the 10 wells shown in the diagrams of water versus gas production (fig. 4-2). All oil-gas ratios are less than $11 \mathrm{bbl} / \mathrm{mmcf}$ and lie in the "wet gas" field of the oil versus gas diagram (fig. 4-3). The six northernmost wells form a cluster on the water-gas production plot (fig. 4-4), characterized by small water decays between initial and 5 years, as shown by the nearly horizontal vectors. Cave Gulch Federal 1 well also shows slow decay of water production. In three other wells (Cave Gulch 13, Branch South Federal B4, and West Cave Gulch 1-36) water decays rapidly. The three wells lowest on structure (Cave Gulch North 4-30, West Cave Gulch State 1-36, and Branch South Federal B4) had the lowest initial and 5-year gas- and water-production rates.

\section{Madden Field}

Considerable amounts of gas have been produced from the upper sandy member of the Cody Shale, the Mesaverde Formation, the lower Fort Union Formation, and the Madison Limestone. The migration of gas from three prominent source rocks into reservoirs within the Madden field is depicted in figure 7. All units between the base of the Waltman Shale Member of the Fort Union Formation and the Jurassic Morrison Formation are overpressured, as indicated by the mud weight contours in figure 7 and by the pressure-depth diagram in figure 8 . The pressure-depth diagram (fig. 8) indicates that an elevated hydrostatic gradient exists below the top of the lower member of the Fort Union Formation and that an interval of even higher overpressure exists below the top of the Mesaverde Formation. This two-compartment pressure signature has not been observed elsewhere in the Wind River Basin. The following sections discuss the gas, water, and oil production from these three formations as portrayed on plates 5-7. Well locations are shown on the map on plate 5. The 26 production diagrams are labeled with letters $\mathrm{A}-\mathrm{Z}$ and the corresponding production interval is indicated by its letter on the cross section on plate 5 . Zones in wells not on the cross section have been projected to the cross section. In several wells, a formerly producing interval was abandoned and the well was recompleted in another interval. For example, well A in the Cody Shale (pl. 5) produced from completion intervals A1 and A2, which are shown on the cross section on plate 5 . In addition to production from the three formations documented on plates 5 and 6, production from the Madison Limestone is displayed on plate 7.

\section{Cody Shale}

Production is from sandstones in the upper sandy member of the Upper Cretaceous Cody Shale, which are commonly referred to as the Shannon and Sussex sandstones (Dunleavy and Gilbertson, 1986; Finn, 2007). The blanket-like character of these sandstones is apparent on the cross section of plate 5 . Sixteen production intervals (A1, A2, B1, ... L) are shown in twelve well $\operatorname{logs}(\mathrm{A}, \mathrm{B}, \ldots \mathrm{L})$ at the bottom of plate 5 . Dry gas is produced from all wells, as indicated by the lack of any oil production. Of the 16 production intervals we examined, initial gas production ranged from 567 to $16,333 \mathrm{mcf} /$ day and water production ranged from 7 to $243 \mathrm{bbl} /$ day (fig. 6-9 of pl. 6). Half of these producing intervals produced a limited amount of water initially, as shown by the eight data points (D, $\mathrm{K}, \mathrm{C}, \mathrm{G}, \mathrm{E} 2, \mathrm{H}, \mathrm{J}$, and I) positioned next to and parallel with the limiting line for water dissolved in reservoir gas (fig. 6-9). The average water-gas ratio of these eight producing intervals was $3.6 \mathrm{bbl} / \mathrm{mmcf}$. Of these, production intervals $\mathrm{G}, \mathrm{H}, \mathrm{I}, \mathrm{J}$, 

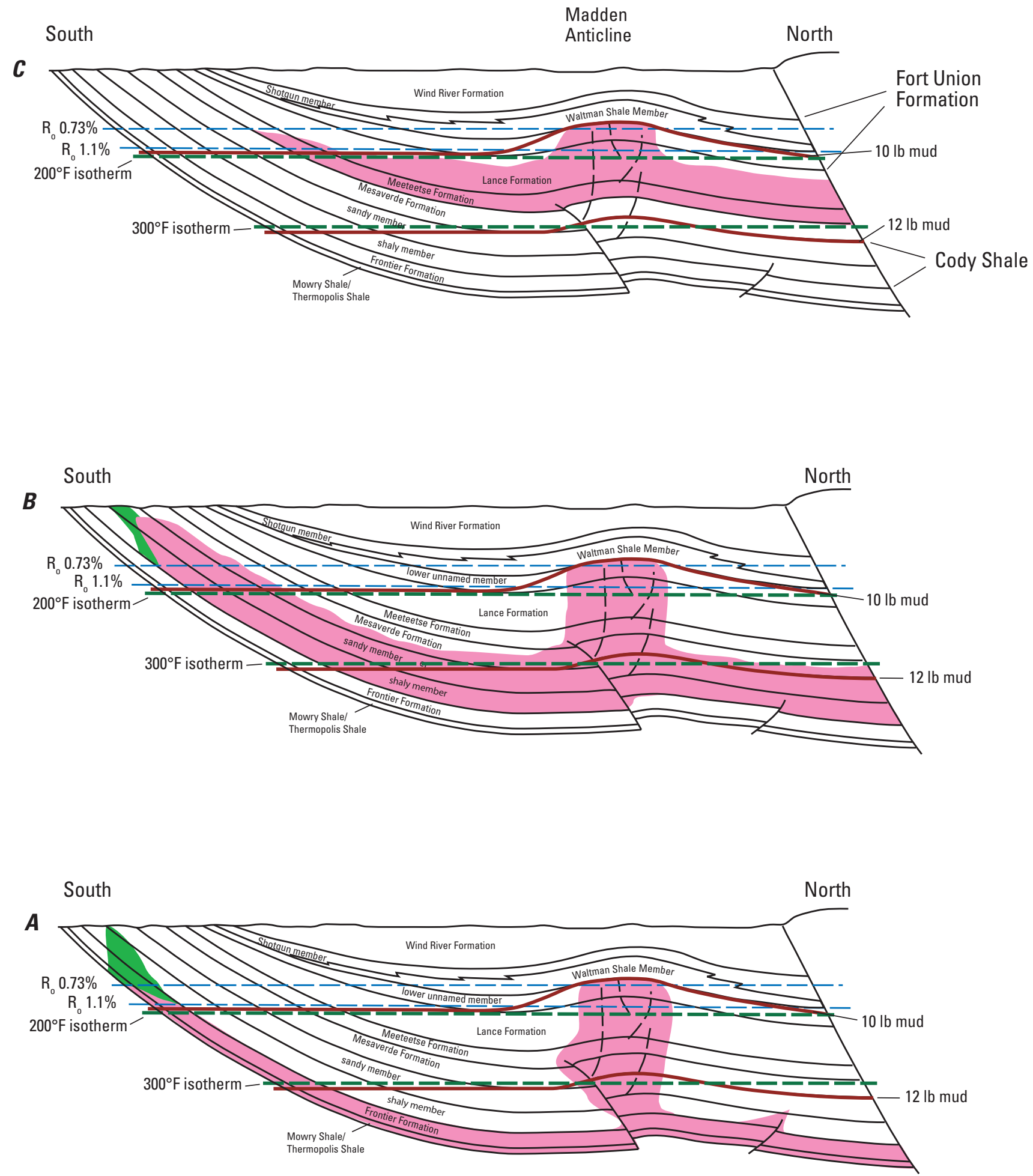

Figure 7. Conceptual distribution of gas along a south-north section in the Wind River Basin. Gas derived from $A$, Mowry Shale, $B$, shaly member of Cody Shale, $C$, Meeteetse Formation. Pink area, thermogenic gas; green area, oil. Solid red line, mud weight contour; dashed blue line, vitrinite reflectance contour; dashed green line; isotherm. ${ }^{\circ} \mathrm{F}$, degree Fahrenheit; $\mathrm{lb}$, pound; $\mathrm{R}_{0}$, vitrinite reflectance. From Johnson and others $(2007$, fig. 25). 


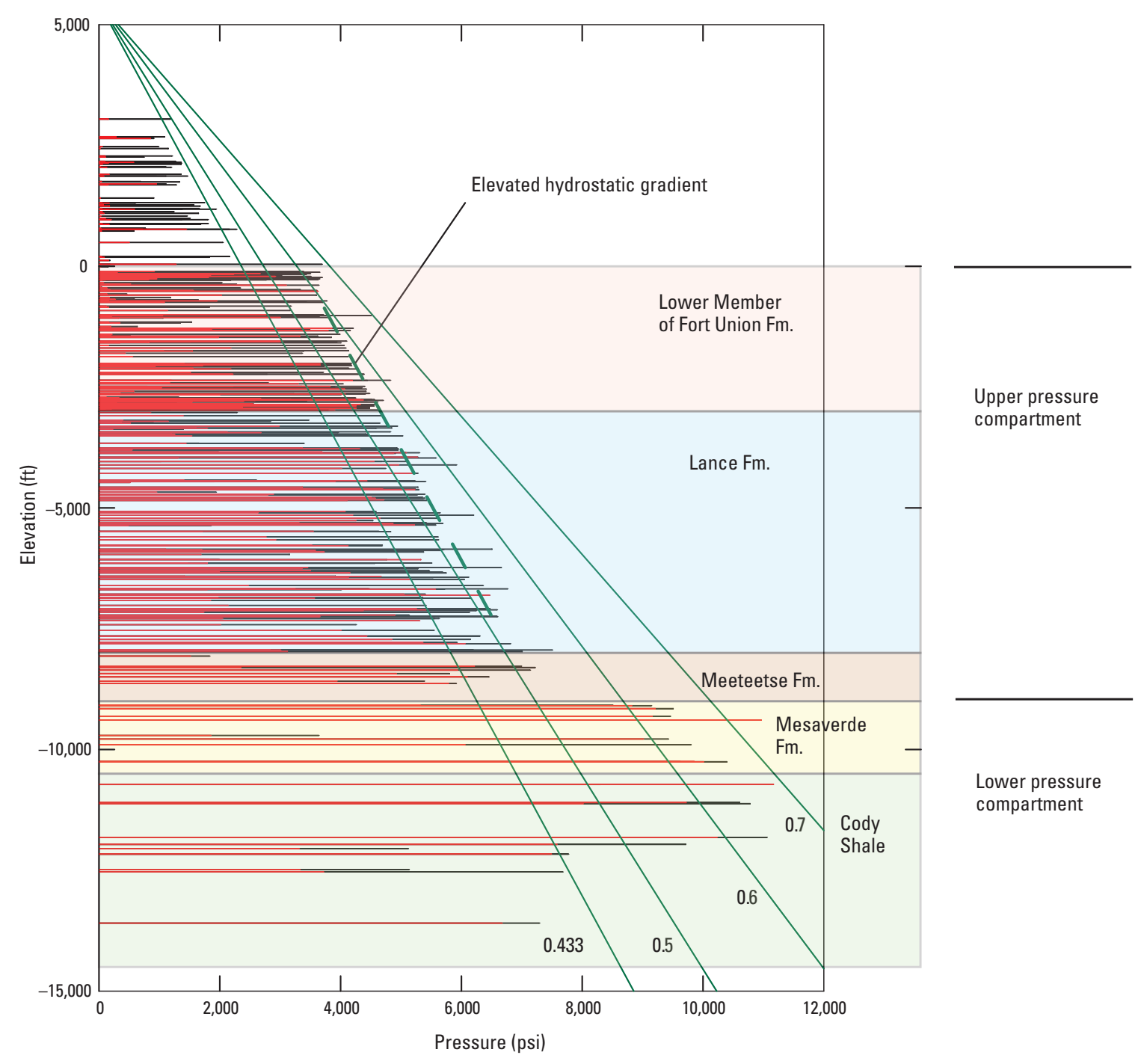

Figure 8. Pressure from drillstem tests as a function of depth in the Madden field. Black needle represents maximum shut-in pressure, red needle represents flowing pressure. Flowing pressure is generally a small fraction of shut-in pressure, as is the case here for elevations shallower than mean sea level. In overpressured compartments below sea level, flowing pressure is a large fraction of shut-in pressure. Formation boundaries are those of wells on the crest of Madden anticline. Pressure data provided by the Wetterhorn Company (2004). Fm., formation; ft, feet; psi, pounds per square inch.

and $\mathrm{K}$ are in wells located east of wells A, B, E, F, which have higher water-gas ratios, but the high water-gas ratio of well $\mathrm{L}$ and the low ratio of wells $\mathrm{C}$ and $\mathrm{D}$ make it difficult to establish a geographic control on water-gas ratios. The highest initial water-gas ratio, recorded in production interval B2, is $148 \mathrm{bbl} / \mathrm{mmcf}$. The vector diagrams (figs. 6-11, 6-12), based on 11 records, show that water decreased with time in 6 cases, remained almost unchanged in 2 cases, and increased in 3 cases.

\section{Mesaverde Formation}

Production from the Upper Cretaceous Mesaverde Formation was sampled with eight production intervals in six wells (M, N, O, P, Q, R; pl. 5) on the west half of the crest of the Madden anticline. The geologic cross section shows no correlatable sandstone intervals between wells, as expected in this fluvial setting. Of the 8 production intervals, 3 produced water at water-gas ratios that can be attributed to water of 
condensation, 2 produced at water-gas ratios of around $5 \mathrm{bbl} / \mathrm{mmcf}$, and 3 produced at extremely high water rates-water-gas ratios exceed $100 \mathrm{bbl} / \mathrm{mmcf}$ (fig. 6-5 of pl. 6). Well location does not appear to determine water production, as the two wells ( $\mathrm{N}$ and $\mathrm{R}$ ) with very high water production rates and water-gas ratios are the westernmost and easternmost of the six wells producing from the Mesaverde Formation (production diagrams and map of pl. 5). Dry gas is produced from all wells, as shown by the lack of any oil production (pls. 5, 6). The vector diagrams (figs. 6-7, 6-8) show 2 producing intervals with constant gas and increasing water production, 2 intervals with decreasing gas and not much change in water production, and 2 intervals with small decreases in gas and water production during a 5-year period.

\section{Lower Fort Union Formation}

The lower Fort Union Formation (Paleocene) was sampled in 11 producing intervals in eight wells distributed along the eastern part of the crest of the anticline (pl. 5). Wells shown on plates 5 and 6 lie within a sandy fluvial facies of the lower Fort Union Formation (Johnson, 2007, figs. 24, 25; pl. 3 of this report). The geologic cross section (pl. 5) shows no correlatable sandstone intervals between wells, as expected in this fluvial setting. Six wells were completed during the years 1968 to 1971 and began producing before 1975, the time at which production records were available. However, gas and water production are fairly constant with time (pl. 5), so the initial sample is assumed to represent early production even though it was acquired 4 or 5 years after production began rather than within 2 years of commencement. Seven of 11 intervals produced from perforations not far below the top of the lower member (base of the Waltman Shale Member) (pl. 5); however, depth does not play a role in water rate or the water-gas ratio (fig. 6-1 of pl. 6). Water-gas ratios vary by two orders of magnitude (fig. 6-1), and all exceed the upper limit for water of condensation. Oil-gas ratios are fairly consistent among the 11 sampled intervals and are characteristic of a wet gas (fig. 6-2). The vector diagrams are tightly clustered (figs. 6-3, 6-4), particularly in comparison with the vector diagrams for the Mesaverde Formation and Cody Shale (figs. 6-7, 6-8, 6-11, 6-12), reflecting the low decline rates that are apparent in the production time diagrams (pl. 5).

\section{Madison Limestone}

The highest gas production rates in the Madden field come from the Mississippian Madison Limestone (pl. 7), a carbonate formation with good permeability. Depths to Madison reservoirs range from 23,600 to $24,400 \mathrm{ft}$ in the Bighorn 2-3, Bighorn 1-5, and Bighorn 4-36 wells. Gas rates of 22 to $43 \mathrm{mmcf} /$ day are constrained by surface facilities and the increase of both water and gas with time are attributed to changes in surface facilities. Water-gas ratios of approximately
$10 \mathrm{bbl} / \mathrm{mmcf}$ (fig. 7-2 of pl. 7) are attributed to water in solution in reservoir gas; the dissolved water volume is high owing to a reservoir temperature of $420^{\circ} \mathrm{F}$ (Brown and Shannon, 1989). No condensate is produced, so this gas is dry (fig. 7-3). The gas is believed to be derived from Cretaceous source rocks across faults (Johnson and others, 2007, fig. 63 of that report). Pressure cannot be much above normal, because in the Bighorn 1-5 well, the Madison was drilled with 10.5-pound mud with no significant gas shows (Dunleavy and Gilbertson, 1986).

\section{Madden Field - Influences on Gas and Water Production}

The following features regarding gas and water production from the Madden field can be seen in the vector and normalized vector diagrams of plate 6 :

- Increases and decreases in water production were greater in the Cody Shale than in either the Mesaverde or lower Fort Union Formations. (The yellow vectors (fig. 6-12) are longer than red vectors (fig. 6-8) and blue vectors (fig. 6-4).)

- Decreases in gas production were least in the lower Fort Union Formation - that is, the gas decline rate was lower in that unit than in the Cody Shale or the Mesaverde Formation. (The X-components of the blue vectors (fig. 6-4) are shorter than $\mathrm{x}$-components of the red vectors (fig. 6-8) or yellow vectors (fig. 6-12).)

- Water production either increased or decreased with time: Cody Shale (fig. 6-12), 3 increases and 7 decreases; Mesaverde Formation (fig. 6-8), 3 increases and 3 decreases; lower Fort Union Formation (fig. 6-4), 3 increases and 5 decreases.

- Figures 6-3, 6-7, and 6-11 show that changes in gas and water production are not related to their initial production rates - that is, there is no grouping of vector length or angle with respect to initial magnitudes (black squares).

To explain these observations, we propose that two different fluid-flow systems presently exist in the Madden field, one for gas and one for water. Our main pieces of evidence in this somewhat speculative discussion are the present-day pressure profile in the Madden anticline (fig. 8) and a cross section and diagram that show burial history, thermal maturity, times of gas generation, and evidence for changing tectonic regimes (pl. 8). The burial history for the Bighorn 1-5 well and timing of gas and oil generation (lower half of pl. 8) are taken from Roberts, Finn, and others (2007).

To develop the argument, we next consider (1) the nearly coincident timing of compressional deformation and gas 
generation, and the consequent development of the present-day pressure compartments; (2) the period of tectonic extension; and (3) the relatively minor effect of uplift and erosion.

\section{Laramide Compressional Deformation and Gas Generation}

Dunleavy and Gilbertson (1986) summarized the evidence for (1) early structural growth of the Madden anticline during Late Cretaceous Meeteetse and Lance deposition, and (2) a possible quiescent period during deposition of the upper part of the lower member and Waltman Shale Member of the Paleocene Fort Union Formation, followed by (3) development of the Madden thrust in Eocene time (pl. 8). Using depositional and structural field evidence in the Badwater area some 10 miles east of the Madden anticline, Love (1978) interpreted a series of tectonic events in the late Paleocene and early Eocene that record compressional features (pl. 8). Most prominent of these events was the thrusting of the Bighorn Mountains southward, overturning Paleocene and older strata in the northeastern Wind River Basin.

Gas generation commences when a Type-III source rock reaches a level of thermal maturity characterized by a vitrinite reflectance $\left(\mathrm{R}_{\mathrm{o}}\right)$ of 0.5 percent (Roberts, Finn, and others, 2007). Commencement of gas generation (pl. 8, solid dots) by six source rocks is coincident with the intersection of a formation boundary with a 0.5 percent $\mathrm{R}_{\mathrm{o}}$ line on the burial history chart. Similarly, peak gas generation (triangles) is determined when a formation attains a thermal maturity of 0.8 percent $R_{o}$, and gas generation (squares) ends when a formation reaches and exceeds 2.0 percent $R_{0}$. Gas generation by Mesaverde and older formations was completed by the end of the major compressional period at the end of early Eocene (pl. 8). In addition to directly generating gas, the lower shaly member of the Cody Shale and the Mowry Shale (which is an oil-prone (Type-II) source rock) contributed gas to the system as its thermal maturity increased to the point at which oil cracked to gas. Peak generation of oil cracking to gas is defined at a transformation ratio of 0.5 for that process. Conversion of oil to gas terminated in early Eocene for the Mowry Shale and in middle Eocene for the lower shaly member of the Cody Shale (pl. 8).

Pressure data from drillstem tests reveal two pressure compartments (fig. 8, pl. 8). On the basis of drillstem pressure data, the top of the lower pressure compartment is near the top of the Mesaverde Formation (fig. 8). Molecular and isotopic analyses of gases also indicate the existence of two compartments separated at the Mesaverde level (Schelling and Wavrik, 1999). On the basis of well log character (Nelson and Kibler, 2007) and the reduction in mud weight at the top of the Paleozoic (Dunleavy and Gilbertson, 1986), the base of the lower pressure compartment appears to be near the top of the Morrison Formation.
Overpressuring in the lower pressure compartment is attributed mainly to gas generation in the Mowry Shale, Cody Shale, and Mesaverde Formation that peaked during Laramide deformation (pl. 8). Thermal maturity in the lower shaly member of the Cody Shale exceeded 1.1 percent $R_{o}$ around $60 \mathrm{Ma}$, just prior to formation of the Madden anticline. Additional gas was supplied by the cracking of oil to gas in two oil-prone source rocks, the Mowry Shale and the lower shaly member of the Cody Shale (pl. 8). Subsidence rates were high ( 300 meters per million years $(\mathrm{m} / \mathrm{m} . \mathrm{y})$.$) to medium$ ( $\sim 150 \mathrm{~m} / \mathrm{m} . \mathrm{y}$.$) during Laramide tectonism (pl. 8), on the basis$ of parameters used for burial-history modeling of the Bighorn 1-5 well (Roberts, Finn, and others, 2007, table 2). The high rate of subsidence of $300 \mathrm{~m} / \mathrm{m}$.y. during deposition of the Lance Formation at the close of Cretaceous time could have caused overpressure development prior to gas generation in the Meeteetse and older formations. Early overpressuring of this type, commonly referred to as compaction disequilibrium, requires a top seal that prevents loss of water during burial. A tongue of marine Lewis Shale within the Meeteetse Formation in the northeastern portion of the basin (Johnson and others, 2007, fig. 14; Johnson, 2007, fig. 17 and pl. 3) could have provided such a seal, although others have alluded to a structural discontinuity at the Mesaverde level (Schelling and Wavrek, 1999). The combination of rapid burial and a high rate of gas generation resulted in overpressuring that exists to the present, as shown by the drillstem test pressure data (fig. 8) as well as by decreases in sonic velocity and resistivity (Nelson and Kibler, 2007). Despite subsequent fracturing and regional uplift and exhumation, the effects of this initial overpressuring persist in the Madden anticline as a pressure compartment extending from the top of the Mesaverde Formation to the top of the Morrison Formation. High pore pressure reduces effective stress. Because of reduced effective stress, the lower overpressured interval was prone to faulting and fracturing during Laramide compression and the ensuing period of tectonic extension.

The upper pressure compartment extends from the base of the Meeteetse Formation to the top of the lower Fort Union Formation, where the overlying Waltman Shale Member forms a thick seal (fig. 8). As burial continued, gas was generated throughout Eocene time from Meeteetse, Lance, and Fort Union source rocks (pl. 8), providing a source of gas for the upper pressure compartment. The elevated hydrostatic gradient in the upper compartment (fig. 8) has been attributed to uplift of a sealed, water-dominated, normally pressured system rather than to overpressuring owing to gas (Nelson and Kibler, 2007). If this interpretation is correct, there is no evidence that the upper compartment was ever overpressured as a result of gas generation. If so, then effective stress remained high in the upper compartment, and that compartment may be less faulted and fractured than the lower pressure compartment-at the least, the style of faulting and fracturing can be expected to be different in the two pressure compartments. 


\section{Tectonic Extension}

Evidence for extension in or adjacent to the Wind River Basin comes from several sources, as listed below. Timing of these extensional events is indicated in the annotated burial history chart for the Bighorn 1-5 well (pl. 8).

- In a study of the Granite Mountains (fig. 1), Love (1970) documented the existence of volcanic vents in the Rattlesnake Hills area during middle and late Eocene time and the subsidence of the Granite Mountains and the development of the Split Rock syncline southeast of the Wind River Basin.

- Blackstone (1990) stated that extensional tectonism is common in the Wind River Basin and that "extensional faults occur in the hanging wall of the Owl Creek Thrust Fault and trend subparallel to the major fault. The faults are the result of extension during the bowing upward (folding) of the toe of the hanging wall of the fault and are in the nature of a "keystone"... ."

- North of the Madden anticline, the southern end of the Bighorn Mountains downdropped after Miocene deposition ceased (Love, 1978).

- Normal faults in the Wind River Formation (Love and Christiansen, 1985), oriented east-west and extending westward for 20 miles from the center of the Madden anticline, demonstrate extension after deposition of the Eocene Wind River Formation.

Given that post-Laramide extension occurred in the region, the question then becomes whether extensional features exist in the subsurface in the hanging wall of the Madden thrust. Dunleavy and Gilbertson (1986, p. 145) issue a somewhat cautionary note: "Large-scale normal faulting occurred in late Tertiary along the leading edge of the Owl Creek system, but there is only a little evidence in well control for significant normal faults at Madden (Reid, 1978)." On the other hand, an interpreted seismic section (Ray and Keefer, 1985; that report's fig. 8) shows normal faults orthogonal to and above the Madden thrust fault, terminating upward in the Waltman Shale Member. Further, an interpreted seismic section in our custody shows a single normal fault just north of the Inexco MDU Deep 1 well with large offsets extending from Cody Shale upward into the lower Fort Union Formation and terminating in the Waltman Shale Member. Accordingly, the existence of subsurface normal faults antithetical to the Madden thrust seems sufficiently substantiated. Likewise, on the basis of core and three-dimensional seismic surveys, strata in the Madden anticline are regarded as extremely fractured and faulted (C. Hawkins, oral communication, 2008). However, the distribution and characteristics of fractures that developed during extension on the Madden anticline are unknown.
Gas generation in the Cody Shale and Mesaverde Formation had largely ceased by the end of the early Eocene and the beginning of tectonic extension (pl. 8). Overpressure, presently between 0.6 and $0.7 \mathrm{psi} / \mathrm{ft}$, was probably higher and could have been high enough to reduce the minimum effective stress to nearly zero and induce opening-mode fractures. It is also reasonable to think that faulting and fracturing is greater in the Mesaverde-Morrison interval than in the overlying Meeteetse-Lance-lower Fort Union interval, owing to high pore pressure and consequent reduced effective stress.

Gas generation in the Lance and Fort Union Formations spans both the compressional and extensional phases (pl. 8). It is possible that high pore pressure was a factor in fracture formation, but the overpressure signature existing today is produced by an elevated hydrostatic gradient, not by a relict overpressured gas signature. Gas generation in the Lance and Fort Union persisted throughout the Eocene and Oligocene and into Miocene time, during the period of tectonic extension. The timing of extension is uncertain, but for the sake of discussion, we designate gas generated during extension as "later" and gas generated prior to extension as "earlier." The "later" gas could have entered newly formed fractures and migrated upward under buoyant pressure. If gas did migrate in fractures, then we can expect to find "later" gas accumulated in more porous reservoirs at some distance from source rocks and "earlier" gas in "tight" reservoirs adjacent to source rocks. The pressure record indicates that gas quantities were insufficient to drive water from the upper pressure compartment.

On the basis of its pressure gradient, the pore space of upper pressure compartment, which extends from the base of the Waltman Shale Member to the top of the Mesaverde Formation, appears to be dominated by water, not by gas. Two possibilities exist: (1) only a fraction of mobile water was displaced from any "reservoir" because insufficient quantities of gas were generated to displace the water, and, as a consequence, water remained the continuous phase; or (2) any overpressure signature caused by early gas generation has been lost because fractures that opened during the extension phase are water filled, causing equilibration along a (now elevated) hydrostatic pressure gradient. In either case, the now-elevated hydrostatic pressure gradient is a relic of a normal hydrostatic pressure gradient that existed before regional uplift and erosion.

\section{Regional Uplift and Erosion}

Regional uplift and erosion commenced about $15 \mathrm{Ma}$ (Roberts, Finn, and others, 2007). The consequent reduction in vertical and horizontal stresses allowed existing fractures to open further. Except for the lower Fort Union Formation, gas generation had ceased before Miocene time and in particular before commencement of uplift and erosion, so the enhanced 
fracture permeability did not result in a redistribution of gas. Fractures now form permeable conduits to aquifers, probably for distances considerably greater than the drainage area of gas to a well. The relative independence of water and gas production rates, the variations in water-gas ratios, and the commencement of water flow with gas flow all indicate that the present-day gas and water flow networks are largely independent.

\section{A Speculative Model}

One possible explanation for the independence of gas and water production in the Madden field is that gas is drawn from one storage and flow system, and water is drawn from another. The burial history chart (pl. 8) shows that gas generation and emplacement first occurred when burial was most rapid and a compressive tectonic regime existed during Laramide deformation. We hypothesize that a second set of permeable fractures was created later, during a period of post-Laramide stress relaxation and extension. Gas remained largely trapped in the pore and fracture system where it had been emplaced during compression, while water entered the newly formed fracture system. An individual well penetrating a gas-charged sandstone draws both gas and water from natural and induced fractures, but the gas is drawn from a volume relatively near the well, whereas the water is drawn from a much larger, fracture-connected volume. This concept is summarized in an idealized sketch of a producing well (fig. 9).

Thus we propose a two-step scenario governing the distribution of fluids in the Cody Shale and Mesaverde Formation: gas generation and emplacement under a compressive stress regime followed by fracture formation during a subsequent period of stress relaxation and extension. However, an added complication occurred in the overlying Meeteetse, Lance, and Fort Union Formations, where gas continued to be generated during the extensional period, after compression had ceased and before commencement of uplift. This "later" gas entered fractures where it could migrate under buoyancy drive and be distributed more widely than gas that had been generated during late Laramide compression. This model remains speculative because of several unknowns: (1) the exact timing of extension, (2) the intensity and character of small-scale fracturing, (3) the orientation and scale of large fractures, and (4) poor understanding of water migration in fractured systems.

\section{Interfield Comparisons of Fluid Production}

Gas, water, and oil production "initial" values of the eight fields presented on plates 1-7 are summarized in figures 10 and 11. Two reservoirs with conventional characteristics, Fuller Reservoir (Shotgun Member) and Madden (Madison), plot separately from the cluster of six tight gas accumulations (fig. 10). The water-gas character of Fuller Reservoir is not directly comparable with the character of other accumulations shown in figure 10 because economic recoveries in this field are determined by the production of oil, not gas. The other exception is the Madison Limestone in the Madden anticline, considered a conventional reservoir, which does produce water that is dissolved in reservoir gas (fig. 7-2 of pl. 7).

Six gas accumulations clustered in the center of figure 10-Frenchie Draw (lower Fort Union), Cooper (lower Fort Union), Cave Gulch (Lance), Madden (lower Fort Union), Madden (Mesaverde), and Madden (Cody)—had gas production rates ranging from 100 to $10,000 \mathrm{mcf} /$ day, water production rates ranging from 1 to more than 1,000 bbl/day, and water-gas ratios ranging from 1 to more than $100 \mathrm{bbl} / \mathrm{mmcf}$. All six are generally categorized as tight gas accumulations, although permeabilities cited for Cave Gulch (Lance) exceed 1.0 mD. The water-gas ratio was consistently greater in Frenchie Draw and Cooper Reservoir than in the other four accumulations, partly because gas production rates were comparatively lower in these two fields. In only two of these six accumulations-Madden (Mesaverde) and Madden (lower Fort Union)_-were some water-gas ratios low enough to indicate that all produced water was dissolved in gas in the reservoir. In other words, almost all producing intervals produced water at rates greater than could be sustained by water dissolved in gas.

Values of vitrinite reflectance $\left(\mathrm{R}_{\mathrm{o}}\right)$ were added to the oil-gas diagram (fig. 11) to represent the approximate thermal maturity of each reservoir. The three deepest accumulations in the Madden field have $\mathrm{R}_{\mathrm{o}}$ values greater than 2.0 percent and produce dry gas with no oil. Wet gas is produced from the lower Fort Union at Madden and the Lance at Cave Gulch, with values of 0.8 and 0.7 percent $R_{0}$, respectively. No $R_{o}$ value could be assigned to Cooper Reservoir field. The $\mathrm{R}_{\mathrm{o}}$ value of 1.1 percent associated with production from Frenchie Draw field is anomalously high. A value of 0.5 percent $R_{o}$ represents Fuller Reservoir field; its source is the underlying Waltman Shale Member. No relationship between vitrinite reflectance and water-gas production was observed, so no corresponding diagram is shown. Thus, the degree of thermal maturity might influence the oil (condensate)-to-gas ratio, but it has no bearing upon water-gas ratio.

Vector and normalized vector diagrams demonstrate the differences in water and gas production among six tight gas accumulations (figs. 12, 13). Of the six gas accumulations, water and gas declines were the most uniform in Cooper Reservoir (lower Fort Union). Uniform declines were also observed in the main part of Cave Gulch (Lance) field (the steep declines in water production were in wells south and west of the Cave Gulch anticlinal structure; see fig. 4-1 of pl. 4). From the relatively uniform declines and the general tracking of water and gas, we infer that water and gas are produced from the same rock volumes and that, among the six accumulations, these two fields are the least perturbed by fracture systems. 


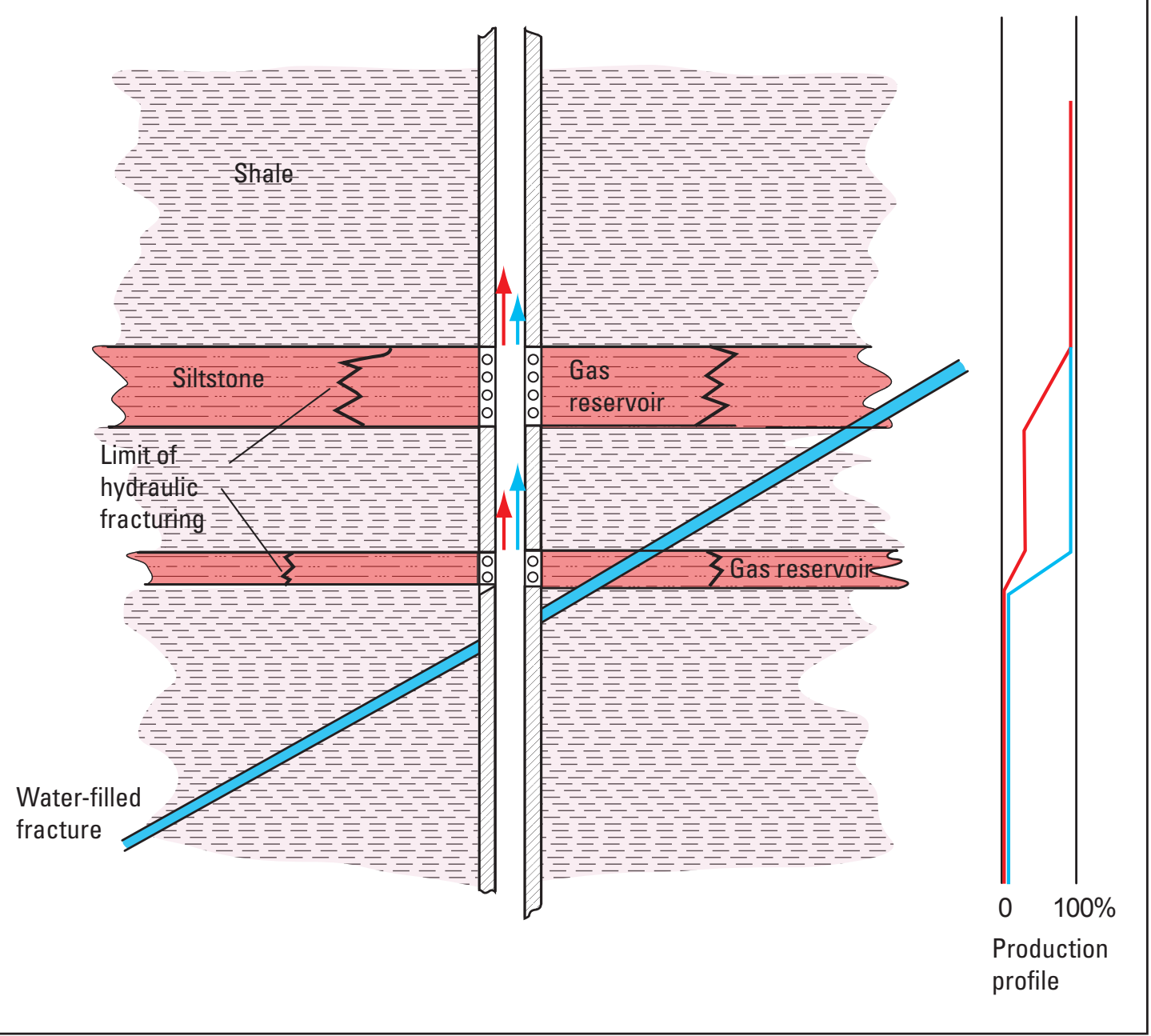

Figure 9. Conceptual diagram of gas and water flow into a well producing from two siltstones in the Madden field. Gas migrates to the wellbore through fractures opened by hydraulic fracturing. Water migrates from distant sources through a single fracture and then into fractures opened by hydraulic fracturing. The production profile shows water entering the wellbore through the lower set of perforations and gas entering through both sets of perforations. Open circle, perforation; red arrow and line, gas; blue arrow and line, water. 


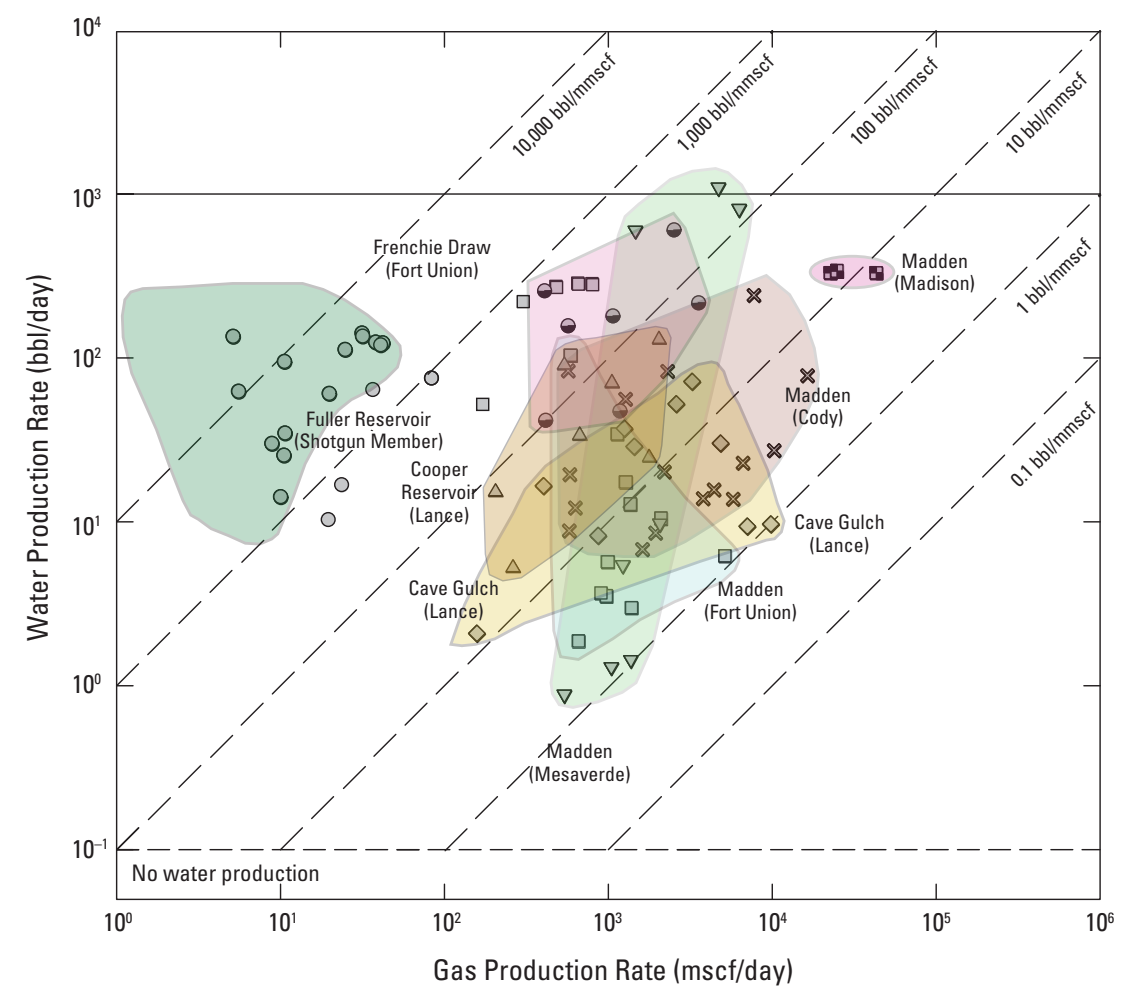

Figure 10. Water versus gas production rates in five fields, Wind River Basin. Each point represents the initial production rate of a single producing interval, taken from plates $1-4,6$, and 7 , and coded by field. Colored backgrounds outline the range of water and gas production rates for each field. The fields designated Madden (Madison) and Fuller Reservoir (Shotgun Member) are considered conventional reservoirs; all others are tight gas accumulations. $\mathrm{bbl} / \mathrm{day}$, barrels per day; bbl/mmscf, barrels per million standard cubic feet; mscf/day, thousand standard cubic feet per day. Well symbols: circle, Fuller Reservoir (Shotgun Member); circle half filled, Frenchie Draw (Fort Union); upright triangle, Cooper Reservoir (Fort Union); inverted triangle, Madden (Mesaverde); square, Madden (Fort Union); square with two filled quadrants, Madden (Madison); ×, Madden (Cody); diamond, Cave Gulch (Lance). 


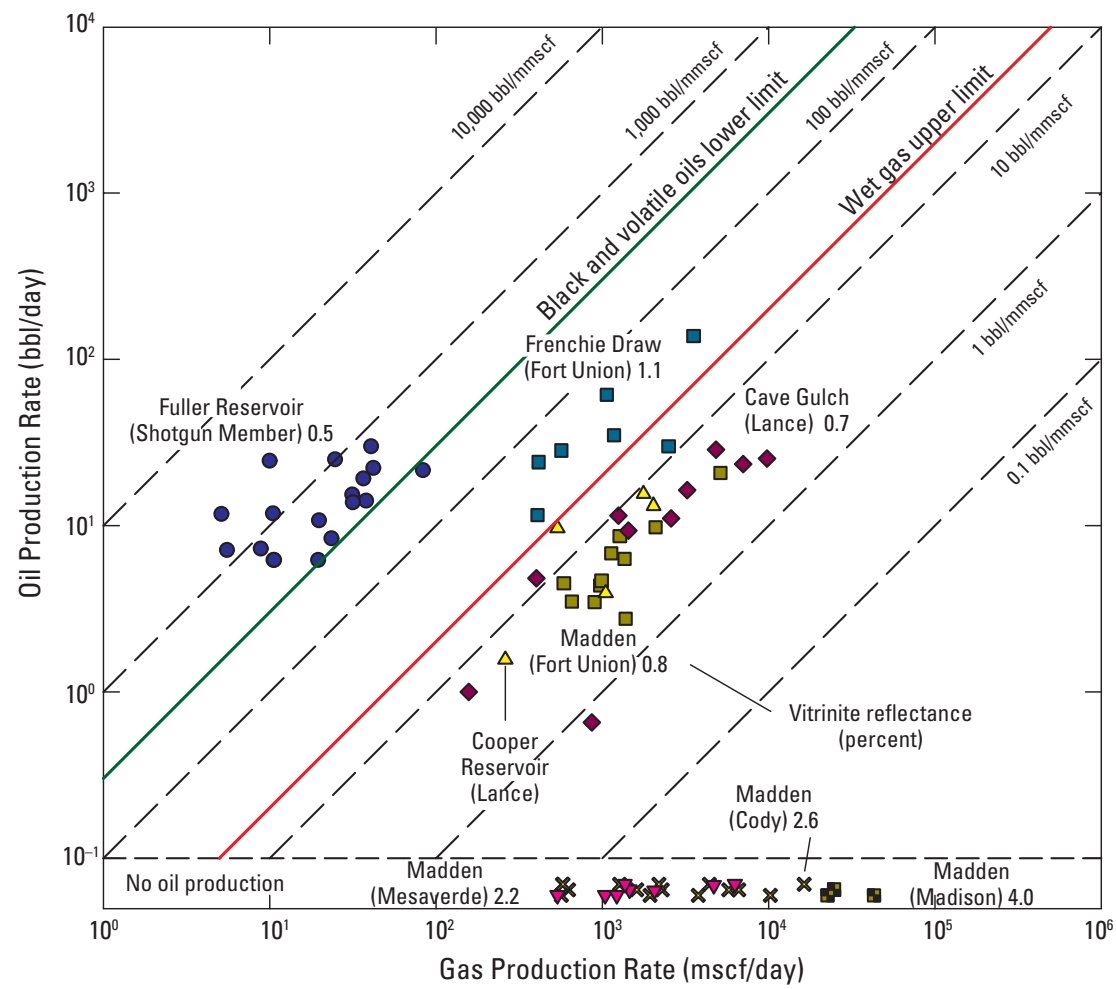

Figure 11. Oil and gas production in eight fields, Wind River Basin. Each point represents the initial production from a single producing interval, coded by field. For example, gas production rates from the Madden (Mesaverde) accumulation are shown as inverted triangles. Vitrinite reflectance values (number following field name) from Nelson and Kibler (2007). bbl/day, barrels per day; bbl/mmscf, barrels per million standard cubic feet; mscf/ day, thousand standard cubic feet per day. Well symbols: purple circle, Fuller Reservoir (Shotgun Member); blue square, Frenchie Draw (Fort Union); upright yellow triangle (Cooper Reservoir); inverted red triangle, Madden (Mesaverde); brown square, Madden (Fort Union); square with two filled quadrants, Madden (Madison); $\times$, Madden (Cody); dark red diamond, Cave Gulch (Lance). 

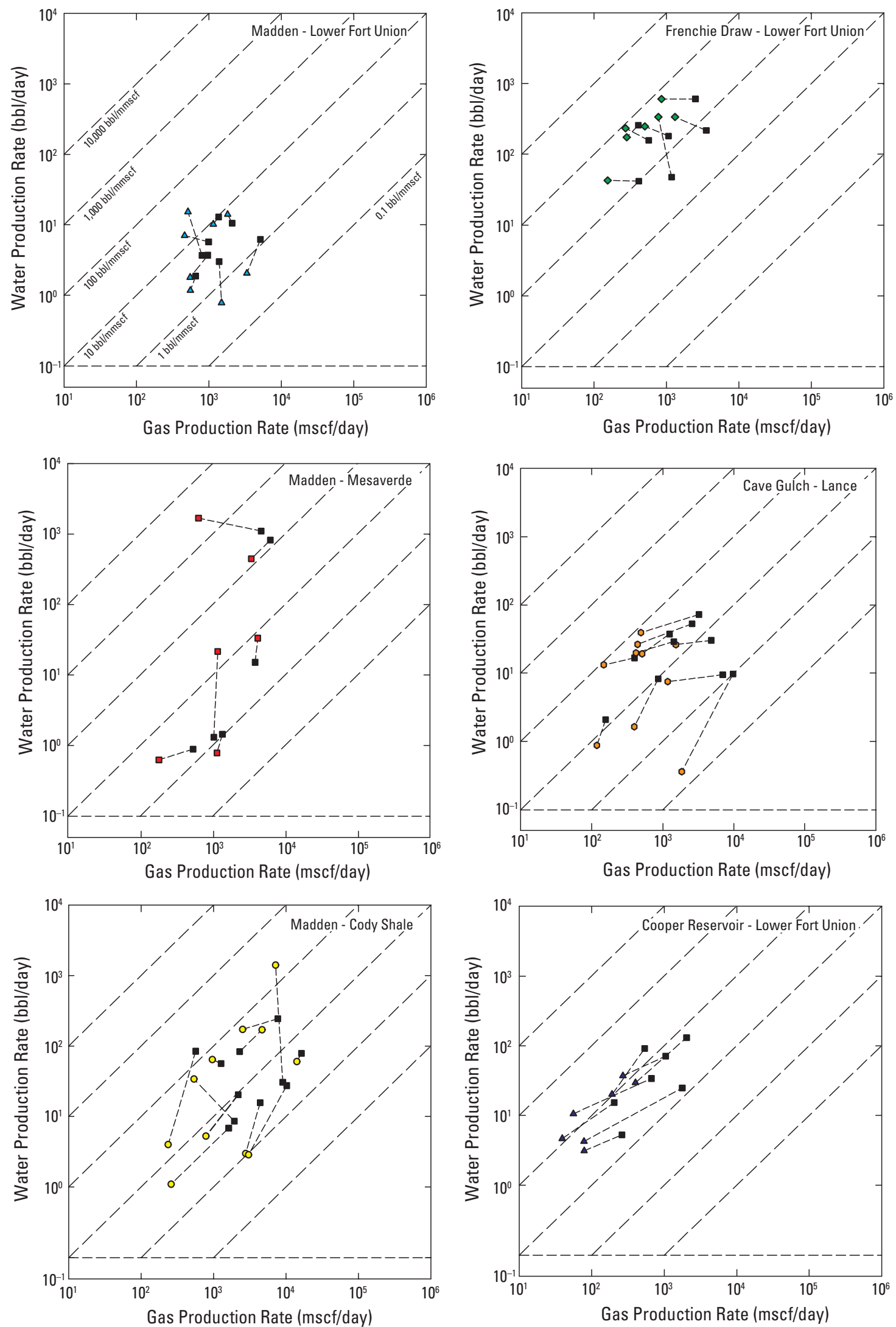

Figure 12. Vector diagrams of six tight gas accumulations, Wind River Basin. Black square, gas and water production at about 2 years; attached symbol, gas and water production about $2+5$ years. bbl/day, barrels per day; mscf/day, thousand standard cubic feet per day. 

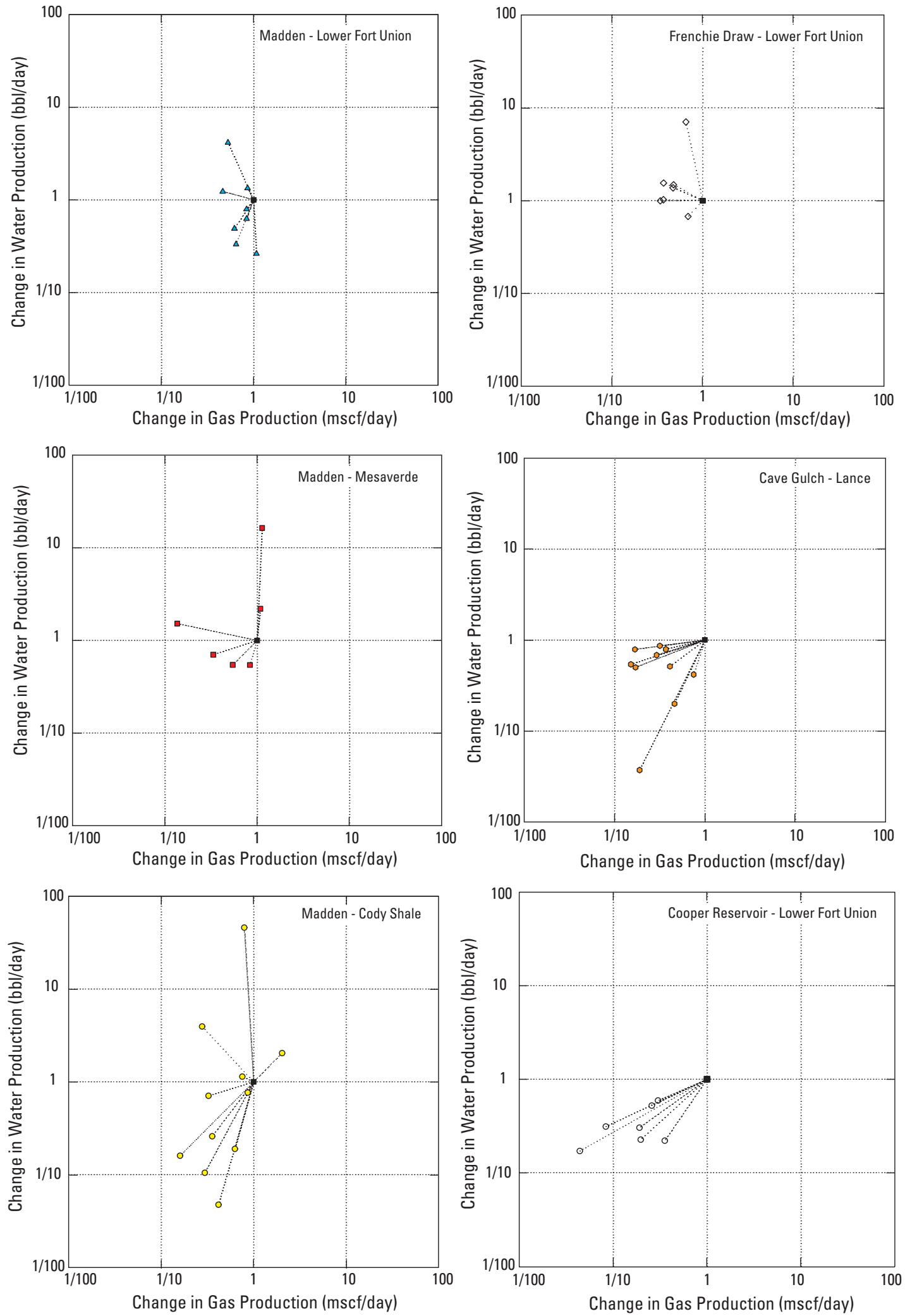

Figure 13. Normalized vector diagrams for six tight gas accumulations, Wind River Basin. Black square in center of diagram, gas and water production at initial time for all vectors; attached symbol, gas and water production 5 years after initial time. bbl/day, barrels per day; mscf/day, thousand standard cubic feet per day. 


\section{Summary and Conclusions}

If one considers the three fields producing from the lower Fort Union (Frenchie Draw, Cooper Reservoir, and Madden), examination of their vector diagrams (figs. 12,13) shows that the three accumulations responded differently with time. In Frenchie Draw wells, gas declined slowly with time and at about the same rate as in Madden, but water was unchanging with time (with one exception), whereas water production either increased or decreased with time in Madden. Both gas and water declined at much higher rates in Cooper Reservoir than in either Frenchie Draw or Madden. The differences in water production may indicate that fracturing plays a smaller role in Cooper Reservoir and Frenchie Draw than it does in Madden.

On the other hand, production-time diagrams of fluids produced from the three tight gas Madden field accumulations-Cody Shale, Mesaverde Formation, and lower Fort Union Formation-show little or no correlation between gas and water, with consequent disparate signatures among wells on the vector diagrams (figs. 12 and 13). Fractional change in gas and water production during a 5-year period was greatest in the Cody Shale and least in the lower Fort Union Formation. Water production generally commenced with gas production and increased or decreased with time while gas production generally decreased. Well position along the Madden anticline does not seem to control fluid production. The initial magnitude of gas production was not a determinant of either the magnitude or the sense of subsequent water production. We conclude that gas and water production from tight gas accumulations in the Madden field are generally independent of one another, and a speculative model linking tectonics, timing of gas generation, and fracture flow has been proposed.

\section{Acknowledgments}

We benefitted from discussions with Ted Enterline of Bill Barrett Corporation, Dean Dubois of EnCana Corporation, Connie Hawkins of Hawkins Oil and Gas, and Ron Baugh, consulting geologist, and from reviews by Steve Roberts and Troy Cook of the U.S. Geological Survey. Ron Johnson, U.S. Geological Survey, supplied formation tops for the Lance and Fort Union Formations in the Madden area. Well locations are taken from the web site of the Wyoming Oil and Gas Conservation Commission. Shauna Ewald, a U.S. Geological Survey student employee, assisted with data preparation.

\section{References Cited}

Blackstone, D.L., Jr., 1990, Rocky Mountain foreland structure exemplified by the Owl Creek Mountains, Bridger Range, and Casper Arch, central Wyoming: Wyoming Geological Association 41st Annual Field Conference Guidebook, p. 151-166.

Boyd, J.B., 1969, Cooper Reservoir field, in Barlow, J.A., Jr., ed., Symposium on Tertiary rocks of Wyoming, Wyoming Geological Association 21st Annual Field Conference Guidebook, p. 111-114.

Brown, R.G., and Shannon, L.T., 1989, The \#2-3 BighornAn ultra-deep confirmation well on the Madden anticline, in Gas resources of Wyoming: Wyoming Geological Association 40th Annual Field Conference Guidebook, p. 181-187.

Dempsey, B.J., Taki, H., and Druyff, J.C., 2001, Case history of hydraulic fracture optimization in tight gas wells with water production in the Wind River Basin, Wyoming: Society of Petroleum Engineers Paper 67300, 11 p.

Dunleavey, J.M., and Gilbertson, R.L., 1986, Madden anticline-Growing giant: Wyoming Geological Association Symposium—Rocky Mountain Oil and Gas Fields, p. 107-157.

Finn, T.M., 2007, Subsurface stratigraphic cross sections of Cretaceous and Lower Tertiary rocks in the Wind River Basin, central Wyoming, Ch. 9, in U.S. Geological Survey Wind River Basin Assessment Team, Petroleum systems and geologic assessment of oil and gas in the Wind River Basin Province, Wyoming: U.S. Geological Survey Digital Data Series DDS-69-J, 17 p.

IHS Energy Group, 2007, U.S. production and well data: Englewood, Colo., database available from IHS Energy Group, 15 Inverness Way East, D205, Englewood, Colo. 80112, U.S.A.

Johnson, R.C., 2007, Detailed measured sections, cross sections, and paleogeographic reconstructions of the Upper Cretaceous and Lower Tertiary nonmarine interval, Wind River Basin, Wyoming, Ch. 10, in U.S. Geological Survey Wind River Basin Assessment Team, Petroleum systems and geologic assessment of oil and gas in the Wind River Basin Province, Wyoming: U.S. Geological Survey Digital Data Series DDS-69-J, 43 p. 
Johnson, R.C., Finn, T.M., Kirschbaum, M.A., Roberts, S.B., Roberts, L.N.R., Cook, T., and Taylor, D.J., 2007, The Cretaceous-Lower Tertiary Composite Total Petroleum System, Wind River Basin, Wyoming, Ch. 4, in U.S. Geological Survey Wind River Basin Assessment Team, Petroleum systems and geologic assessment of oil and gas in the Wind River Basin Province, Wyoming: U.S. Geological Survey Digital Data Series DDS-69-J, 96 p.

Keefer, W.R., 1970, Structural geology of the Wind River Basin, Wyoming: U.S. Geological Survey Professional Paper 495-D, 35 p.

Kirschbaum, M.A., Lillis, P.G., and Roberts, L.N.R., 2007, Geologic assessment of undiscovered oil and gas resources in the Phosphoria total petroleum system of the Wind River Basin, Wyoming, Ch. 3, in U.S. Geological Survey Wind River Basin Assessment Team, Petroleum systems and geologic assessment of oil and gas in the Wind River Basin Province, Wyoming: U.S. Geological Survey Digital Data Series DDS-69-J, 27 p.

Love, J.D., 1970, Cenozoic geology of the Granite Mountains area, central Wyoming: U.S. Geological Survey Professional Paper 495-C, 154 p.

Love, J.D., 1978, Cenozoic thrust and normal faulting, and tectonic history of the Badwater area, northeastern margin of Wind River Basin, Wyoming, in Wyoming Geological Association 30th Annual Field Conference Guidebook, p. $235-238$.

Love, J.D., and Christiansen, A.C., 1985, Geologic map of Wyoming: U.S. Geological Survey Special Geologic Map, 3 sheets, scale 1:500,000. McCain, W.D., Jr., 1990, The properties of petroleum fluids: Pennwell Books, Tulsa, Oklahoma, 548 p.

McCain, W.D., Jr., 1990, The properties of petroleum fluids: Pennwell Books, Tulsa, Oklahoma, 548 p.

Montgomery, S.L., Barrett, F., Vickery, K., Natali, S., Roux, R., and Dea, P., 2001, Cave Gulch field, Natrona County, Wyoming-Large gas discovery in the Rocky Mountain foreland, Wind River Basin: American Association of Petroleum Geologists Bulletin, v. 85, no. 9, p. 1543-1564.

Mueller, Clark, 1989, Frenchie Draw, in Wyoming Oil and Gas Fields Symposium-Bighorn and Wind River Basins: Wyoming Geological Association, p. 174-175.
Nelson, P.H., and Kibler, J.E., 2007, Distribution of fluids and pressures in the Wind River Basin, Wyoming, Ch. 7, in U.S. Geological Survey Wind River Basin Assessment Team, Petroleum systems and geologic assessment of oil and gas in the Wind River Basin Province, Wyoming: U.S. Geological Survey Digital Data Series DDS-69-J, 27 p.

Normark, R.M., 1978, Frenchie Draw gas field, in Wyoming Geological Association 30th Annual Field Conference Guidebook, p. 277-280.

Ray, R.R., and Keefer, W.R., 1985, Wind River Basin, Central Wyoming, in Gries, R.R. and Dyer, R.C., eds., Seismic exploration of the Rocky Mountain region, Rocky Mountain Association of Geologists, p. 201-217.

Reid, S.G., 1978, Madden Deep unit-Fremont and Natrona Counties, Wyoming, Wyoming Geological Association Earth Science Bulletin, p. 34-42.

Roberts, L.N.R., Finn, T.M., Lewan, M.D., and Kirschbaum, M.A., 2007, Burial history, thermal maturity, and oil and gas generation history of petroleum systems in the Wind River Basin Province, central Wyoming, Ch. 6, in U.S. Geological Survey Wind River Basin Assessment Team, Petroleum systems and geologic assessment of oil and gas in the Wind River Basin Province, Wyoming: U.S. Geological Survey Digital Data Series DDS-69-J, 25 p.

Roberts, S.B., Roberts, L.N.R., and Cook, T., 2007, Geologic assessment of undiscovered petroleum resources in the Waltman Shale Total Petroleum System, Wind River Basin Province, Wyoming, Ch. 5, in U.S. Geological Survey Wind River Basin Assessment Team, Petroleum systems and geologic assessment of oil and gas in the Wind River Basin Province, Wyoming: U.S. Geological Survey Digital Data Series DDS-69-J, 32 p.

Schelling, D.D., and Wavrek, D.A., 1999, Structural geology and petroleum systems of the Madden field, Wind River Basin, Wyoming [abs.]: American Association of Petroleum Geologists Bulletin, v. 83, no. 13 (supplement).

Specht, R.W., 1989, Fuller Reservoir, in Wyoming Oil and Gas Fields Symposium-Bighorn and Wind River Basins: Wyoming Geological Association, p. 178-180.

Wetterhorn Company, 2004, Drill stem test database for Wind River Basin: 7450 S. Harrison Way, Centennial, Colorado 80122.

Wyoming Oil and Gas Conservation Commission (WOGCC), 2007, Accessed 06/01/2007-08/31/07 at http://wogcc. state.wy.us/. 
Publishing support provided by:

Denver Publishing Service Center

For more information concerning this publication, contact: Team Chief Scientist, USGS Central Energy Resources

Box 25046, Mail Stop 939

Denver, CO 80225

(303) 236-1647

Or visit the Central Energy Resources Team site at: http://energy.cr.usgs.gov/ 
